\title{
Credit Supply: Are there negative spillovers from banks' proprietary trading? (RM/19/005-revised-)
}

Citation for published version (APA):

Kurz, M., \& Kleimeier, S. (2019). Credit Supply: Are there negative spillovers from banks' proprietary trading? (RM/19/005-revised-). Maastricht University, Graduate School of Business and Economics. GSBE Research Memoranda No. 026 https://doi.org/10.26481/umagsb.2019026

Document status and date:

Published: 24/10/2019

DOI:

10.26481/umagsb.2019026

Document Version:

Publisher's PDF, also known as Version of record

\section{Please check the document version of this publication:}

- A submitted manuscript is the version of the article upon submission and before peer-review. There can be important differences between the submitted version and the official published version of record.

People interested in the research are advised to contact the author for the final version of the publication, or visit the DOI to the publisher's website.

- The final author version and the galley proof are versions of the publication after peer review.

- The final published version features the final layout of the paper including the volume, issue and page numbers.

Link to publication

\footnotetext{
General rights rights.

- You may freely distribute the URL identifying the publication in the public portal. please follow below link for the End User Agreement:

www.umlib.nl/taverne-license

Take down policy

If you believe that this document breaches copyright please contact us at:

repository@maastrichtuniversity.nl

providing details and we will investigate your claim.
}

Copyright and moral rights for the publications made accessible in the public portal are retained by the authors and/or other copyright owners and it is a condition of accessing publications that users recognise and abide by the legal requirements associated with these

- Users may download and print one copy of any publication from the public portal for the purpose of private study or research.

- You may not further distribute the material or use it for any profit-making activity or commercial gain

If the publication is distributed under the terms of Article $25 \mathrm{fa}$ of the Dutch Copyright Act, indicated by the "Taverne" license above, 


\title{
Credit Supply: Are there negative spillovers from banks' proprietary trading?
}

\author{
Michael Kurz ${ }^{\mathrm{a}, *}$, Stefanie Kleimeier ${ }^{\mathrm{b}, \mathrm{c}, \mathrm{d}}$ \\ ${ }^{a}$ Financial Markets Division, De Nederlandsche Bank, The Netherlands \\ ${ }^{b}$ Department of Finance, Maastricht University, The Netherlands \\ ${ }^{c}$ Department of Accounting and Finance, Open Universiteit Heerlen, The Netherlands \\ ${ }^{d}$ University of Stellenbosh Business School, Bellville, South Africa
}

\begin{abstract}
Following the global financial crisis, policy makers considered regulations that restrict banks' activities which were motivated by concerns that banks use central bank borrowing, government guarantees, or subsidies to fund securities trading instead of lending to the real economy. Using a global sample of 132 major banks from 2003 to 2016, we find that banks' securities trading is indeed associated with decreased loan supply. Effects are stronger for domestic lending markets, during crisis periods, and in countries with deeper financial markets. However, corporate capital expenditures and employment growth are unaffected, suggesting that policy makers' concerns are only partly justified.

Keywords: Credit Supply, Proprietary Trading, International Lending, Banking, Corporate Loans

JEL Classification: G01, G21, G28
\end{abstract}

*Corresponding author: m.kurz1988@outlook.com

The views expressed herein are those of the authors and do not necessarily reflect official positions of De Nederlandsche Bank. We would like to thank Lu Zhang (Discussant), Jakob de Haan, Joost Bats, Aerdt Houben, Sweder van Wijnbergen, Dirk Broeders, Nicole Branger, Rob Bauer, Stefan Hirth (Discussant), Klaas Mulier, Paul Söderlind, Jaap Bos, Paulo Rodrigues, Peter Schotman, David Martinez-Miera, Thomas Post, Nagihan Mimiroglu, and Runliang Li for very helpful comments and discussions. We would also like to thank seminar participants at Maastricht University, De Nederlandsche Bank, and the CPB Netherlands Bureau for Economic Policy Analysis, as well as the participants of the 15th Corporate Finance Day at Antwerp University. 


\section{Introduction}

Since the 2008 financial crisis, the question of the merits of banks combining traditional commercial banking activities and securities trading has reentered the economic policy debate. The Volcker Rule in the US, the Vickers Report in the UK, and the Liikanen and European Commission proposals in the EU are all intended to limit banks' securities trading activities. Among policy makers' concerns is that banks use central bank borrowing, implicit government guarantees, or direct government subsidies to fund risky securities trading activities instead of granting loans to non-financial firms (Lehmann, 2016; Krahnen, Noth and Schüwer, 2017). In this paper, we explore whether these concerns are justified and whether there is indeed a connection between banks' securities trading and lending. We analyze the effect of banks' securities trading on bank lending over the business cycle including both crisis periods and economically stable periods by analyzing a sample of matched bank-borrower data covering the years 2003 to 2016. Most studies investigating bank lending focus on banking in individual countries or narrow geographical regions. Large banks, however, tend to operate globally across all of their business lines, including lending and securities trading (Gambacorta and van Rixtel, 2013). Therefore, we consider it important to investigate bank loan flows and securities trading activities in a global setting. We exploit a global sample that includes 132 major banks from 21 countries and 7,763 borrowers from 76 countries spanning North America, Europe, and Asia. This enables us to account for foreign lending and differences in the depth of financial markets in which banks operate.

Banks have incentives to allocate funds to securities trading activities at the expense of lending activities (Boot and Ratnovski, 2016). This allows banks to realize short-term profits that are readily scalable, whereas lending requires banks to build and maintain long-term relationships that produce information-based rents only in the long run. The effect intensifies as financial markets become deeper and thus allow for larger trades. Indeed, Edwards and Mishkin (1995) and DeYoung and Rice (2004) show a general trend toward declining profitability in relationship banking since the 1990s due to increasingly deeper financial markets which have also provided borrowers with 
more and cheaper alternatives to bank loans. Moreover, Beck, Demirgüç-Kunt and Levine (2010) document a deepening of, for example, the US financial market since the 1990s, and Svirydzenka (2016) documents similar developments in other countries in Europe and Asia. In such an economic environment, banks have incentives to allocate funds to trading rather than lending activities to increase their level of risk and in turn increase expected returns. De Jonghe (2010), Demirgüç-Kunt and Huizinga (2010), Brunnermeier, Dong and Palia (2012), and De Young and Torna (2013) show that banks' non-lending activities are riskier than their lending activities and that, among non-lending activities, securities trading is the riskiest activity. Thus, banks wishing to increase expected returns have an incentive to increase securities trading while reducing bank lending. However, the presence of implicit or explicit government guarantees exaggerates the incentives for banks to increase their trading activities at the expense of relationship banking, as the funding costs of trading activities do not fully reflect the risks (Krahnen et al., 2017). Since policy makers' primary concern in providing implicit guarantees for banks does not lie with bank profits but with the availability of bank loans to consumers and non-financial firms, market outcomes in which banks increase securities trading and decrease bank lending are likely considered sub-optimal from a policy perspective. The reduction in loan supply due to banks' securities trading activities may have implications for real economic activity. Arping (2013) shows that while allocating funds to securities trading rather than lending can be individually optimal for banks from a profit-maximization perspective, it may hamper growth in the real economy because non-financial firms will find it increasingly difficult to obtain loan financing. An impact on real economic activity would require a situation in which non-financial firms are unable to replace bank loans with market-based forms of financing (Chodorow-Reich, 2014).

Using a regression specification similar to that suggested in Khwaja and Mian (2008), we compare the loan flows to the same borrower from banks with more and less extensive securities trading but otherwise the same characteristics (intensive margin). Our results show that banks with greater securities trading exhibit an approximately $20 \%$ lower annual loan growth than banks with less 
securities trading. Furthermore, we show that the reduction in loan supply due to extensive securities trading also extends to loan flows from new and exiting lending relationships (extensive margin). In line with Boot and Ratnovski (2016), we find that our results are primarily driven by banks that are located in countries with deep financial markets. Exploiting our global sample, we show that banks with extensive securities trading cut loan supply to a greater extent in their domestic market than in foreign lending markets, despite an overall decline in foreign lending. Since securities trading binds capital, this is consistent with the notion that foreign lending comes at the expense of domestic lending when banks are capital constrained (Liu and Pogach, 2017). We also find that more securities trading is associated with higher loan prices measured as the sum of fees and interest spread over LIBOR.

Securities trading by banks also leads to a transmission of shocks from securities prices to bank lending. Adrian and Shin (2013) show that banks' trading-like activities are more cyclical than traditional commercial banking activities. Banks possessing large inventories of securities expose their balance sheets to price volatility in financial markets. If the value of the inventory of securities decreases, banks must realize these reductions under mark-to-market accounting rules. Thus, banks with large values of trading securities on their balance sheets may see significant amounts of their equity being wiped out by losses from securities trading in the event of a significant shock to securities prices. In line with this notion Fahlenbrach, Prilmeier and Stiltz (2012) find that banks with greater securities holdings experienced larger losses during the 2007 financial crisis that wiped out part of the banks' equity. As a consequence, banks reduced their loan supply in an effort to deleverage (Bocola, 2016; Acharya, Eisert, Eufinger and Hirsch, 2018). Furthermore, Acharya, Almeida, Ippolito and Perez (2014a), Acharya, Almeida, Ippolito and Perez (2014b), and Ivashina and Scharfstein (2010) provide evidence that banks reduce lending if their balance sheet strength is compromised. Since depressed securities prices are typically only temporary during financial crises, Diamond and Rajan (2011) and Abbassi, Iyer, Peydro and Tous (2016) argue that banks with limited liability and implicit government guarantees have an incentive to allocate their remaining funds to 
purchase securities at fire-sales prices from sellers in need of liquidity. Thus, banks further reduce loan supply to free up resources for the purchase of securities, leading to a transmission of a shock from securities prices to bank lending (Shleifer and Vishny, 2010; Stein, 2013).

Focusing on the additional impact of financial crises, our results show that the gap in loan supply between banks with more securities trading and those with less securities trading increases even further. We observe approximately $31 \%$ lower loan growth during periods of financial crisis when stress in financial markets is high. This additional effect is driven by differences in financial market depth across bank countries.

Our paper is closely related to Abbassi, Iyer, Peydro and Tous (2016), who show that German banks with trading expertise participated in such fire-sales purchases of assets during the 2007 financial crisis. Beyond the results reported in Abbassi et al. (2016), we show, however, that the global dimension of bank lending and securities matters by gauging the effects on foreign vs. domestic lending and by showing that the negative impact of securities trading on bank lending is driven by financial market depth in banks' home markets. Moreover, while the analysis in Abbassi et al. (2016) only captures the intensive margin, our results also extend to the extensive margin.

Our paper adds to the empirical literature that investigates different types of bank lending channels - i.e., reduced loan supply in response to shocks to banks' balance sheets. Among these channels, the most prominent is the bank lending channel of monetary policy (Bonaccorsi di Patti and Sette, 2012; Jimenez, Ongena, Peydro and Saurina, 2012, 2014). Additionally, Cingano, Manaresi and Sette (2016) and Iyer, Peydro, da Rocha-Lopes and Schoar (2014) consider shocks to interbank lending. Our paper contributes to this literature along two lines. First, similar to Abbassi et al. (2016), we document bank lending channel that negatively affects loan supply through shocks to securities prices. This extents the understanding of potential transmission mechanisms from shocks to financial markets via the banking system to the real economy. Second, our paper investigates the bank lending channel global setting, contributing to the understanding of the transmission of shocks to banks' balance sheets across lending markets in different countries. 


\section{Data and Variables}

We use data on bank lending from Thomson Reuters' LPC DealScan database, which provides extensive coverage of the global corporate loan market. The bank lending data are augmented with bank and borrower characteristics from Standard \& Poor's Compustat database. Since LPC DealScan and Compustat do not share any common identifier, we hand-match all borrower, bank, and loan information. We collect information on corporate loans extended by 132 major banks in 21 countries between 2003 and 2016 to 7,763 non-financial firms in 76 countries, including advanced and emerging economies. The 132 banks in our sample account for approximately $81 \%$ of the total loan amount in the LPC DealScan during our sample period. Consistent with the literature, we aggregate all loans to each bank's parent company (see, e.g., Sufi (2007)) and track bank mergers over our sample period (see, e.g., Schwert (2018)). Our banks are based in the US, Canada, the UK, Austria, Belgium, Denmark, France, Germany, Ireland, Italy, the Netherlands, Spain, Sweden, Switzerland, China, Hong Kong, Taiwan, South Korea, Singapore, Japan, Brazil, and Australia. We further augment our dataset with country-level data on financial market conditions and financial system development from the US Office of Financial Research and the International Monetary Fund.

Our dependent variable is the change in the logarithm of the loan volume by a specific bank to a specific borrower in a given year. In most studies investigating bank loan supply effects, detailed information from national credit registers is used to obtain data on changes in individual loan volumes. While national credit registers provide very detailed information on bank-borrower relationships, they restrict studies to the analysis of only a single country, and few countries have credit registers. Large universal banks tend to operate globally across all of their business lines (see, e.g., Gambacorta and van Rixtel (2013)). Using the LPC DealScan database instead of a national credit register allows us to analyze a global sample of banks and borrowers and to investigate cross-border lending. However, our corporate loan data differ from credit register data in two important ways. First, we cannot observe changes in a particular loan over time because we only observe loans at the time of their origination. Second, the loans in our sample tend to have long maturities. These two properties 
of our loans imply that for a large number of firms, there is no meaningful time-series variation in bank-firm loan volumes. To address this issue, we follow Acharya et al. (2018) and aggregate firms into clusters based on the country of incorporation, the two-digit SIC code, and the median EBITDA interest coverage ratio. We expect firms that are incorporated in the same country and that are active in the same industry to share sufficiently similar characteristics. Furthermore, credit ratings are an important determinant of bank lending. Therefore, firms with the same rating will have similar access to the loan market or other sources of financing (see, e.g., Diamond (1991), Erel, Julio, Kim and Weisbach (2011)). Thus, we further match firms in the country-industry clusters based on their median interest coverage ratio. Thus, our dependent variable is the change in the logarithm of the total USD volume of loans granted by a bank to all firms in the same cluster in a given year. This aggregation of individual firms into clusters leaves us with 23,876 unique bank-firm cluster connections, such that the average firm cluster consists of approximately 4.5 firms. We present the summary statistics for the firm clusters in our sample in Table A.4 in the appendix. The firm clusters in our sample are comparable but rather large in terms of the book value of total assets. However, the clusters are diverse in their leverage and changes in cash holdings, with the net debt-to-assets ratios ranging from $4.3 \%$ to $68.2 \%$ and changes in cash as a share of assets ranging from $-5.3 \%$ to $+8.4 \%$. This clearly indicates variation in the need for bank financing across our firm clusters.

Our main independent variable is a measure of banks' proprietary trading. We measure bank proprietary trading in two ways. First, we measure proprietary trading directly as the volume of a bank's trading account divided by its total assets. The trading account reflects the mark-to-market value of all fixed income and equity securities purchased for resale to other financial institutions or the public in the near term. ${ }^{1}$ Second, consistent with the approach used in Abbassi et al. (2016), we rely on the notion that banks, to maintain or build a strong presence in securities trading and thus to

\footnotetext{
${ }^{1}$ Ideally, we would like to observe when banks buy or sell securities. However, changes in the USD volume of a bank's trading account cannot be used to identify when banks are trading. Since the volume is the product of market price and quantity (mark-to-market value), increases in quantity due to banks' purchases of securities could be offset by the prices of the same securities falling. Therefore, we use the mark-to-market value of a bank's trading account.
} 
accumulate trading expertise, require a specific infrastructure. Arguably, direct trading memberships at important securities exchanges are among the most relevant aspects of such trading infrastructure, as they allow for direct access to the trading floors and trading and clearing systems of the respective exchanges without the need for intermediate brokers.

Thus, for each bank in our sample, we count the total number of trading memberships at Euronext (the European multi-country exchange), the London Exchange, NYSE, NASDAQ, the Toronto Exchange, the Japan Exchange (covering all Japanese exchanges), the Hong Kong Exchange, the Shanghai Exchange, BMnF Bovespa (Brazil), the Australian Securities Exchange, and the Deutsche Börse (the German Exchange). Each of these exchanges has been listed as one of the ten largest exchanges in terms of market capitalization at least once during our sample period. A bank is considered a trading member of one of these exchanges if it has purchased the right to directly access the trading floor. If a bank has access to more than one market of the same exchange (equity, fixed income, and/or derivatives), we count this as one membership at the relevant exchange. ${ }^{2}$

We hand collect the trading membership information from the websites of the relevant exchanges and from company reports. While all banks in our sample offer trading services to their clients, it is not necessary for a bank to possess a trading membership at an exchange to offer such services. Such a bank could handle all trading, including trading on behalf of clients, via external broker-dealers. Even if a bank were to purchase a trading membership to more easily offer trading services to clients, this would hardly require more than a single membership at one or at most two major exchanges. Thus, we would expect banks with a large number of exchange memberships to have strong trading operations, a higher level of trading expertise, and consequently a stronger inclination towards proprietary trading. Our notion of interpreting greater (trading) activity as a sign of greater (trading) expertise is consistent with a large base of theoretical and empirical literature on organizational learning-by-doing (see, e.g., Jarmin (1994), Thompson (2010), Argote and Miron-Spektor (2011)).

\footnotetext{
${ }^{2}$ Note that it is not necessary for foreign banks to possess a banking license in the relevant country to purchase a membership.
} 
Therefore, instead of a simple count variable of the number of exchange memberships as a proxy for trading, we consider a dummy variable that equals one for banks with more than two memberships. This reflects the idea that banks with only one or two memberships use those primarily for clientrelated trading, while true proprietary traders require a larger number of trading memberships in various markets around the world.

Consistent with our argument, Figure 1 indicates that the USD volume of a bank's trading account as a fraction of its total assets tends to be larger the more trading memberships the bank possesses. Note that for all panels in Figure 1, there is an upward jump in securities trading for banks with more than two memberships. This supports the previously outlined approach of defining a trading bank dummy that equals one if a bank has more than two memberships and zero otherwise.

We estimate a correlation coefficient of 0.6 between the number of exchange memberships and the volume of the trading account divided by total assets, which is statistically significant at the one percent level. Moreover, a simple OLS regression of the number of trading memberships on the trading account as a fraction of total assets and a constant yields $R^{2}=0.545$. A larger trading account volume indicates greater securities trading by banks. 
Figure 1: Trading Account and Trading Memberships

Notes: In the boxplot, we show the volume of the securities trading account as a fraction of the total assets for different counts of trading memberships in exchanges. The sample consists of 132 major banks based in 21 countries between 2003 and 2016. Panel a) shows the boxplot for the full sample period, and panels b) to d) show the boxplots for the various sub-periods. The continuous variable (y-axis) represents the USD volume of the trading/dealing account divided by the USD (book value) of total assets. The categorical variable (x-axis) represents the number of trading memberships at major exchanges. We count memberships at Euronext (the European multi-country exchange), the London Exchange, NYSE, NASDAQ, the Toronto Exchange, the Japan Exchange (covering all Japanese exchanges), the Hong Kong Exchange, the Shanghai Exchange, BMnF Bovespa (Brazil), the Australian Securities Exchange, and the Deutsche Börse (the German Exchange).

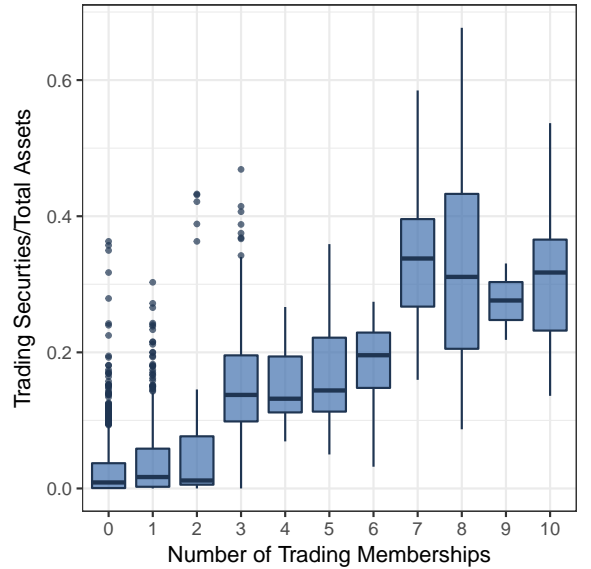

a) Full sample period

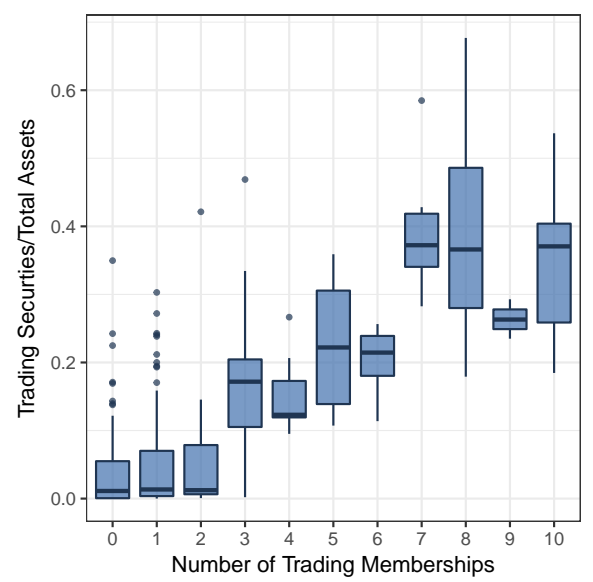

c) Crisis period

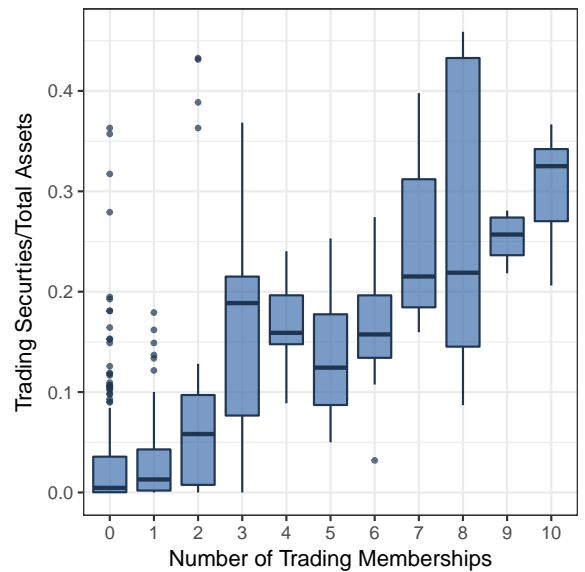

b) Pre-Crisis period

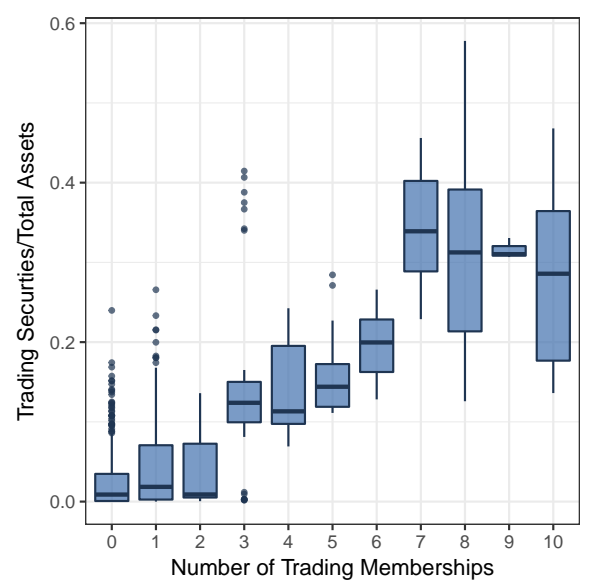

d) Post-crisis period

Securities trading is naturally affected by financial market conditions. Thus, we augment our dataset with the Financial Stress Index developed by the US Office for Financial Research (OFR). The Financial Stress Index is a continuous measure of stress in financial markets that accounts for 
contributions to stress from bond markets, equity valuations, and implied and realized volatility from bond, equity, currency, and commodity markets. Monin (2017) provides details on the construction of the index, data sources, and weights for each index element. The index is centered on zero, where positive values indicate increased stress, and negative values indicate relaxation. Thus, using the index, we can obtain a granular view of financial market conditions over time. Since the index distinguishes three different world regions (the US, other advanced economies, and emerging economies), we can account for the fact that emerging economies were less affected by the 2007-2009 financial crisis than advanced economies were. This impact is documented in, e.g., Blanchard, Das and Faruqee (2010). In particular, emerging Asia was affected to a lesser extent than advanced economies were (see, e.g., Goldstein and Xie (2009), Keat (2009)). Thus, we consider it important to account for these differences. As an alternative to directly using the Financial Stress Index, we create a bank-country-specific dummy variable, Financial Crisis, that equals one if the Financial Stress Index has a value greater than 5 and zero otherwise. The particular cutoff value of 5 is motivated by the fact that the Financial Stress Index is on average 5.55 during the 2007-2009 financial crisis. We show the time series of the Financial Stress Index for the US, other advanced economies, and emerging economies in Figure 2. "Other Advanced Economies" comprises primarily Europe and Japan. An index value of zero suggests that stress is at normal levels, and a positive (negative) value indicates increased (decreased) stress. USA covers the US economy. The index clearly identifies the last financial crisis for all three regions, indicating extreme financial stress during that period. In line with previous research, the index clearly shows less financial stress in emerging economies than in advanced economies (see, e.g., Blanchard et al. (2010), Goldstein and Xie (2009), Keat (2009)). The time series for the US and all other advanced economies almost completely overlap throughout the sample period. These two time series share a correlation coefficient of approximately 0.94, indicating almost perfect co-movement. The correlation coefficient between the time series for the US and the emerging economies is 0.77 , and that for the EU and the emerging economies is 0.84 . This suggests that a simple crisis dummy would be sufficient to capture the crisis timing 
globally but not the severity of the impact. In terms of the severity of the impact of the crisis, it appears to be sufficient to distinguish between advanced and emerging economies. Finally, the bank control variables included in our dataset capture differences in bank size, profitability, and funding. The control variables comprise the logarithm of the book value of total assets, ROA, the capital ratio, liquidity ratio, and the loans-to-deposits ratio. The data for these controls are obtained from Compustat. ROA is computed as the income before extraordinary items, divided by the book value of total assets. The capital ratio is the ratio of the book value of common equity to the book value of total assets. The liquidity ratio is computed as the ratio of cash to total assets. The loans-to-deposits ratio is computed as the ratio of total loans to total deposits. Furthermore, at the borrower level, we use the logarithm of the book value of total assets, capital expenditure divided by total assets, employment growth net of the debt-to-assets ratio, intangible assets-to-assets ratio, and the change in cash and cash equivalents. Net debt is the sum of short-term and long-term liabilities minus cash and cash equivalents. 
Figure 2: Is Financial Stress in Crisis Periods the Same Around the World?

Notes: In this figure, we show the value of the Financial Stress Index of the US Office of Financial Research. The index is a measure of systemic financial stress, capturing contributions to financial stress from credit, equity valuations, funding, safe assets, and volatility. An index value of zero suggests that stress is at normal levels, and a positive (negative) value indicates increased (decreased) stress. Other Advanced Economies covers advanced economies other than the US, primarily the EU and Japan. Emerging covers emerging markets. For details on the index's computation and coverage, see Monin (2017).
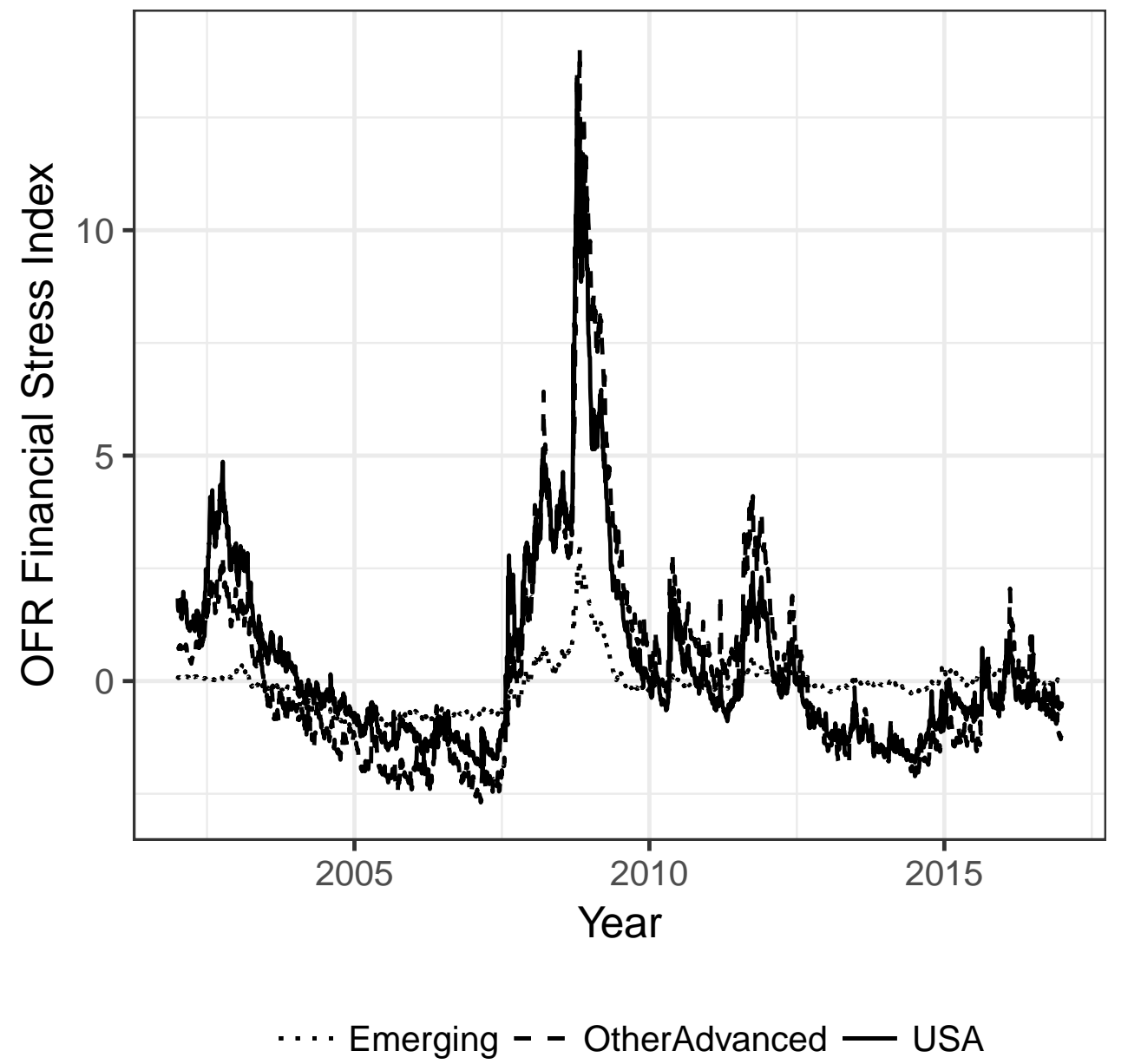


\section{Bank Lending - Empirical Framework}

\subsection{Panel Regression}

Our aim is to investigate whether banks with extensive trading operations provide fewer loans in the corporate loan market than banks with less extensive trading operations. To answer this question, we apply a modified version of the Khwaja and Mian (2008) regression specification. Consider an economy in which firms borrow from multiple banks. Such an economy may experience two kinds of observationally equivalent shocks to bank lending: firm-specific loan demand shocks and bank-specific loan supply shocks. Loan demand shocks reflect unobserved changes to firms' fundamentals, such as shocks to productivity or customer demand. Loan supply shocks reflect changes in banks' funding situations, such as variations in the availability of deposits or short-term liquidity or, as is the focus in this paper, the redirection of available funds from corporate lending to proprietary trading. Therefore, it is necessary to use an econometric specification that allows us to isolate the relevant loan supply effect. Initially, we estimate the following model:

$$
\Delta \log \left(\text { LoanVolume }_{i j t}=\beta \text { Trading }_{i t-1}+\boldsymbol{\delta} \mathbf{X}_{\mathbf{i t - 1}}+\gamma_{j t}+\gamma_{\text {bank country } t}+v_{i j t}\right.
$$

where the dependent variable is the change in the logarithm of the loan volume by bank $i$ to firm cluster $j$ in year $t{ }^{3}$ The main idea of this approach is the use of matched bank-borrower data to track bank-borrower relationships over time. This allows us to use the loan flow from one bank to

\footnotetext{
${ }^{3}$ The use of firm clusters in such a regression may raise a number of concerns. Veredas and Petkovic (2010) demonstrate that aggregating individual observations into groups in panel datasets with a low time frequency (i.e., yearly) does not affect the model structure. The estimated coefficients remain unbiased and correspond to the coefficients of the individual-level regressions. However, heteroskedasticity is introduced due to the aggregation of individual firms. The heteroskedasticity is straightforward to address through the common cluster robust estimator of variance. These statements are easy to verify using standard arguments, and we do so in Appendix C. Thus, for all regressions, we cluster standard errors at the bank and firm-cluster level or at the firm-cluster level, depending on the particular regression specification. Moreover, aggregating individual observations into clusters may also raise concerns regarding Simpson's paradox (see Simpson (1951), Blyth (1972)), i.e., the phenomenon whereby a trend may appear within groups of the data but reverses if the individual observations in the groups are aggregated. However, the inclusion of cluster fixed effects that act as cluster-specific intercepts in our regression models prevents trends in the groups from reversing after aggregating the observations.
} 
one borrower as a dependent variable and to enrich the regression with borrower-level fixed effects and bank-level control variables. The latter will capture supply effects, and the former will capture loan demand. Whereas Equation (1) is represented in reduced form, Khwaja and Mian (2008) shows that it can be derived as an equilibrium condition by explicitly modeling loan supply and demand.

Equation (1) includes two different fixed effects. The borrower $\times$ year fixed effects $\gamma_{j t}$ account for time-varying, unobserved heterogeneity in borrower characteristics that proxy for loan demand (see Khwaja and Mian (2008)). Loan supply effects are captured through the bank characteristics included in $\mathbf{X}_{\mathbf{i t}-\mathbf{1}}$ and in Trading $g_{i-1}$. Thus, in line with our first hypothesis, we expect $\hat{\beta}<0$, indicating that banks with more extensive securities trading reduce loan supply to their corporate borrowers. Since the firm clusters are the same for all banks, $\beta$ indicates how the same borrower's loan growth from one bank changes relative to that from another bank that has less extensive trading operations. We also include bank country $\times$ year fixed effects $\gamma_{\text {bank country } t}$ to account for time-varying macroeconomic conditions and regulatory environments in a bank's country of incorporation. Moreover, we include a vector $\mathbf{X}_{\mathbf{i t - 1}}$ of one-year-lagged bank control variables in our model, where $\delta$ denotes the corresponding vector of the regression coefficients. Jimenez, Mian, Peydro and Saurina (2011) argue that if unobservable borrower characteristics that affect the lending relationship were systematically correlated with the extent of securities trading, then there should be a sizable difference in estimated $\beta$ s when estimating Equation (1) with borrower $\times$ year fixed effects $\gamma_{j t}$ and without these fixed effects. Such a correlation would imply that some borrowers have a preference for borrowing from banks with large trading operations. Therefore, comparing the sign and magnitude of estimated $\beta$ in Equation (1) with and without fixed effects $\gamma_{j t}$ provides us with some intuition regarding the importance of such borrower behavior in our sample. Our coefficient of interest is $\beta$, where Trading $_{i t-1}$ is either bank $i$ 's trading account divided by total assets or a dummy variable indicating whether bank $i$ has more than two trading memberships at different securities exchanges. Since total assets include both trading securities and loans, we use the one-year-lagged trading securities to total assets ratio to avoid any purely mechanical connection 
with the change in loan volume.

The regression specification in Equation (1) is a variant of the current workhorse model for disentangling loan demand from loan supply effects in empirical banking research. In particular, if some borrowers have a preference for borrowing from banks with large trading operations, it is important to use the fixed effects specification in Equation (1). However, Paravisini, Rappoport and Schnabl (2017) and Repullo (2018) raise concerns that time-varying borrower fixed effects may not fully absorb loan demand effects. If that were the case, then we could not interpret the estimated coefficient $\beta$ as a pure supply-side effect, and its interpretation would be unclear. To mitigate such concerns, we also apply an alternative approach, suggested by Repullo (2018), and replace the borrower $\times$ year fixed effects with a set of borrower characteristics $\mathbf{H}_{\mathbf{j t}}$ and borrower country $\times$ year fixed effects $\gamma_{\text {Borrower country } t}$ and borrower industry $\times$ year fixed effects $\gamma_{\text {Borrower SIC } t \text {. The }}$ latter are included to control for country- and industry-level loan demand shocks. The corresponding regression model is represented in Equation (2).

$$
\begin{array}{r}
\Delta \log (\text { LoanVolume })_{i j t}=\tilde{\beta} \text { Trading } g_{i t-1}+\boldsymbol{\delta} \mathbf{X}_{\mathbf{i t}-\mathbf{1}}+\boldsymbol{\eta} \mathbf{H}_{\mathbf{j t}}+ \\
+\gamma_{\text {Borrower country } t}+\gamma_{\text {Borrower SIC } t}+\gamma_{\text {bank country } t}+\tilde{v}_{i j t},
\end{array}
$$

As suggested by Repullo (2018), if borrower $\times$ year fixed effects indeed sufficiently absorb loan demand effects, then we expect the estimated coefficients $\beta$ in Equation (1) and $\tilde{\beta}$ in Equation (2) to have the same sign and to be similar in magnitude. ${ }^{4}$ Therefore, by comparing our regression results from Equation (1) and Equation (2), we test the ability of borrower $\times$ year fixed effects $\gamma_{j t}$ to account for loan demand effects.

\footnotetext{
${ }^{4}$ Note that one advantage of the specification suggested by Repullo (2018) is that estimation is not restricted to multiple-bank borrowers as in the Khwaja and Mian (2008) specification. However, since all of our firm clusters borrow from multiple banks, this is of little concern in our specific application.
} 


\subsection{Crisis Impact}

The fire sale hypothesis on bank trading (see, e.g., Abbassi et al. (2016), Diamond and Rajan (2011))) suggests that any negative effect of trading on loan supply should be stronger during periods of financial crisis characterized by high volatility and falling asset prices than in periods of stability. We therefore interact Trading $_{i t-1}$ with the Financial Stress Indicator $F S I_{i t}$ and estimate the following regression equation:

$$
\begin{aligned}
\Delta \log \left(\text { LoanVolume }_{i j t}=\beta \text { Trading }_{i t-1}\right. & +\phi F S I_{i t}+\xi\left(\text { Trading }_{i t-1} F S I_{i t}\right) \\
& +\delta \mathbf{X}_{\mathbf{i t}}+\gamma_{j t}+\gamma_{\text {bank country }}+v_{i j t},
\end{aligned}
$$

In this specification, the marginal effect of Trading $_{i t-1}$ depends on the level of stress in the financial market and is given by $\hat{\beta}+\hat{\xi} \times F S I_{i t}$. Under the fire sale hypothesis, we expect $\hat{\xi}<0$. Note that because the Financial Stress Indicator $F S I_{i t}$ is bank country specific, we have to replace the bank country $\times$ year fixed effects with bank country fixed effects. ${ }^{5}$

\section{Main Results on Bank Lending}

In this section, we present the results of the estimation of our models in Equations (1), (2), and (3). In columns (3) and (4) of Table 1, we report the results for Equation (1). For the exchange membership dummy, Trading Memberships, we find a negative, statistically significant $\beta$ coefficient that indicates an approximately $20 \%$ reduction in loan supply relative to banks with fewer than 2 trading memberships. Using Securities Trading as our trading proxy also yields a negative, statistically significant coefficient of similar magnitude. However, the economic size of the effect is smaller. A one-standard-deviation increase in Securities Trading corresponds to a decrease in loan supply of approximately 7.6\%. Overall, this supports our hypothesis that banks' trading activity

\footnotetext{
${ }^{5}$ Implicitly, we assume that stress in the financial markets of a bank's home region is the most influential on the bank's trading behavior.
} 
negatively affects loan supply. Both trading proxies yield effects that are not only statistically significant but also economically meaningful. Columns (1) and (2) present the results of our model in Equation (1) estimated without the firm cluster $\times$ year fixed effects. Columns (3) and (4) show the results when we include firm cluster $\times$ year fixed effects. The $\beta$ coefficients are similar, but the difference in coefficients for Securities Trading is larger than the difference for Trading Memberships but is not statistically significant. ${ }^{6}$ These differences in the estimated coefficients reflect potential bias induced by endogenous matching between borrowers and banks that is absorbed by firm cluster $\times$ year fixed effects.

Columns (5) to (6) contain the estimation results for the specifications in which firm cluster $\times$ year fixed effects are replaced with firm cluster characteristics, industry $\times$ year fixed effects, and country $\times$ year fixed effects as described in Equation (2). The estimated coefficients associated with Trading Memberships and Securities Trading under the specification of columns (5) to (6) are remarkably similar to those obtained in columns (3) and (4). This suggests that the coefficients indeed can be interpreted as supply effects and that the fixed effects in our Khwaja and Mian (2008) specification in Equation (1) sufficiently control for variations in loan demand. However, the specifications in columns (3) and (4) yield a higher adjusted $R^{2}$ than any of the other specifications, suggesting that this specification fits the data better. Therefore, we maintain the firm cluster $\times$ year fixed effects setup as our preferred specification.

\footnotetext{
${ }^{6}$ The estimated coefficients for Securities Trading in columns (1) and (3) both lie within one another's 95\% confidence intervals.
} 
Table 1: Securities Trading and Bank Lending

Notes: In this table, we present the results for the regressions defined in Equations (1) and (2). The unit of observation is firm cluster-bank-year. Firm clusters are formed based on a firm's country of incorporation, the two-digit SIC code, and a firm's credit rating, estimated based on the median EBIT interest coverage ratios. Trading Memberships equals one if a bank has more than two trading memberships at securities exchanges and zero otherwise. Securities Trading is the one-year-lagged USD value of a bank's trading account divided by its total assets. Columns (1) to (2) show the results for Equation (1) estimated without firm cluster $\times$ year fixed effects, columns (3) and (4) show the corresponding results including the firm cluster $\times$ year fixed effects. Columns (5) and (6) show the results for Equation (2). Associated estimated coefficients for the borrower-level controls in columns (5) and (6) are reported in Table B.1 in the Appendix. Standard errors are clustered at the bank-firm cluster level. Significance levels: ${ }^{*} p<0.1 ;{ }^{* *} p<0.05 ;{ }^{* * *} p<0.01$.

Dependent variable: $\Delta \log (\text { Loan Volume })_{i j t}$

(1)

\begin{tabular}{|c|c|c|c|c|c|c|}
\hline & $(1)$ & $(2)$ & (3) & (4) & $(5)$ & (6) \\
\hline Securities Trading $_{i, t-1}$ & $\begin{array}{l}-0.165 \\
(0.119)\end{array}$ & & $\begin{array}{c}-0.215^{* *} \\
(0.106)\end{array}$ & & $\begin{array}{c}-0.278^{* * *} \\
(0.107)\end{array}$ & \\
\hline Trading Memberships ${ }_{i}$ & & $\begin{array}{c}-0.188^{* * *} \\
(0.030)\end{array}$ & & $\begin{array}{c}-0.195^{* * *} \\
(0.027)\end{array}$ & & $\begin{array}{c}-0.193^{* * *} \\
(0.027)\end{array}$ \\
\hline $\log (\text { Total Assets })_{i, t-1}$ & $\begin{array}{c}0.311^{* * *} \\
(0.011)\end{array}$ & $\begin{array}{c}0.328^{* * *} \\
(0.011)\end{array}$ & $\begin{array}{c}0.486^{* * *} \\
(0.012)\end{array}$ & $\begin{array}{c}0.506^{* * *} \\
(0.012)\end{array}$ & $\begin{array}{c}0.453^{* * *} \\
(0.011)\end{array}$ & $\begin{array}{c}0.470^{* * *} \\
(0.012)\end{array}$ \\
\hline 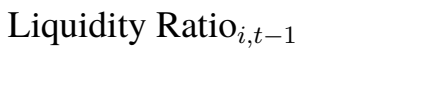 & $\begin{array}{l}0.647^{* *} \\
(0.337)\end{array}$ & $\begin{array}{c}0.217 \\
(0.327)\end{array}$ & $\begin{array}{c}1.735^{* * *} \\
(0.325)\end{array}$ & $\begin{array}{c}1.353^{* * *} \\
(0.319)\end{array}$ & $\begin{array}{c}1.429^{* * *} \\
(0.325)\end{array}$ & $\begin{array}{c}1.040^{* * *} \\
(0.318)\end{array}$ \\
\hline Capital Ratio $_{i, t-1}$ & $\begin{array}{c}2.499^{* * *} \\
(0.685)\end{array}$ & $\begin{array}{c}2.434^{* * *} \\
(0.685)\end{array}$ & $\begin{array}{c}3.928^{* * *} \\
(0.615)\end{array}$ & $\begin{array}{c}3.854^{* * *} \\
(0.598)\end{array}$ & $\begin{array}{c}3.561^{* * *} \\
(0.617)\end{array}$ & $\begin{array}{c}3.603^{* * *} \\
(0.605)\end{array}$ \\
\hline Loans-To-Deposits $_{i, t-1}$ & $\begin{array}{c}0.079^{* * *} \\
(0.031)\end{array}$ & $\begin{array}{c}0.060^{* * *} \\
(0.031)\end{array}$ & $\begin{array}{c}0.159^{* * *} \\
(0.029)\end{array}$ & $\begin{array}{c}0.145^{* * *} \\
(0.029)\end{array}$ & $\begin{array}{c}0.143^{* * *} \\
(0.029)\end{array}$ & $\begin{array}{c}0.133^{* * *} \\
(0.029)\end{array}$ \\
\hline $\mathrm{ROA}_{i, t-1}$ & $\begin{array}{c}6.945^{* * *} \\
(2.493)\end{array}$ & $\begin{array}{c}4.676 \\
(2.509)\end{array}$ & $\begin{array}{c}6.502^{* * *} \\
(2.106)\end{array}$ & $\begin{array}{l}4.592^{* *} \\
(2.119)\end{array}$ & $\begin{array}{c}6.951^{* * *} \\
(2.199)\end{array}$ & $\begin{array}{l}5.439^{* *} \\
(2.211)\end{array}$ \\
\hline Firm Cluster-Year FE & NO & NO & YES & YES & NO & NO \\
\hline Bank Country-Year FE & YES & YES & YES & YES & YES & YES \\
\hline Firm Cluster Controls & NO & $\mathrm{NO}$ & NO & NO & YES & YES \\
\hline Borrower Country-Year FE & NO & NO & NO & NO & YES & YES \\
\hline Borrower SIC-Year FE & $\mathrm{NO}$ & $\mathrm{NO}$ & $\mathrm{NO}$ & $\mathrm{NO}$ & YES & YES \\
\hline Observations & 267,326 & 267,326 & 267,326 & 267,326 & 267,326 & 267,326 \\
\hline Adjusted $\mathrm{R}^{2}$ & 0.075 & 0.076 & 0.375 & 0.376 & 0.215 & 0.216 \\
\hline
\end{tabular}

In Table 2, we present the estimation results for the regression specification including the interaction term with the financial stress measure as described in Equation (3). In Table 2, Financial Stress denotes the Financial Stress Index. The Financial Stress Index is not a crisis indicator in this sense. Only large values indicate a financial crisis, while the index fluctuates around zero throughout the business cycle. We also define an alternative proxy, the Financial Crisis dummy, that isolates the 
impact of the 2008 financial crisis. Thus, Financial Crisis denotes a dummy variable that equals one if the value of the Financial Stress Index is greater than 5 and zero otherwise, where values of the Financial Stress Index above 5 correspond to the 2008 financial crisis period (years 2007 - 2009) in our sample. Columns (1) to (2) contain results for the regression specification using Securities Trading as a measure of banks' trading. Only the interaction terms between Securities Trading and the Financial Crisis dummy and the Financial Stress index are negative and statistically significant, while the direct effect of Securities Trading is not significant. This suggests that the loan-reducing effect of securities trading occurs primarily during the financial crisis, when stress in financial markets peaks. Columns (3) to (4) contain results using the Trading Memberships dummy as a measure of banks' trading. Using the Trading Memberships dummy as proxy for banks' trading, we find similar results. The economic size of the effect of banks' trading on lending is substantial. The marginal effect associated with Trading Memberships during the financial crisis is a $31.13 \%$ reduction in loan supply relative to banks with fewer trading memberships. The coefficient associated with Trading Memberships in column (4) captures the effect of securities trading for Financial Stress Index values of zero, i.e., in the absence of either positive or negative stress. The negative and statistically significant coefficient associated with the interaction term indicates that banks with more extensive securities trading tend to reduce their loan supply by an additional 4.11 percentage points per unit increase in financial stress relative to the $20 \%$ baseline reduction (statistics are approximate). In contrast, we do not find a significant effect for the Financial Stress Index alone. While evidently there was a considerable impact of the 2008 financial crisis on the corporate loan market, this could suggest that the Financial Stress Index can capture the direct link between the crisis and lending but only through banks' securities trading activities. 
Table 2: Securities Trading and Bank Lending during the Crisis

Notes: In this table, we present the results for the regressions defined in Equation (3). The unit of observation is firm cluster-bank-year. Firm clusters are formed based on a firm's country of incorporation, the two-digit SIC code, and a firm's credit rating, estimated based on the median EBIT interest coverage ratios. Trading Memberships equals one if a bank has more than two trading memberships at securities exchanges and zero otherwise. Securities Trading is the one-year-lagged USD value of a bank's trading account divided by its total assets. Financial Stress is the value of the Financial Stress Indicator as provided by the US OFR for a bank's country of incorporation. Financial Crisis is a dummy variable that equals one if financial stress is above 5 and zero otherwise. Standard errors are clustered at the bank-firm cluster level. Significance levels: ${ }^{*} p<0.1 ;{ }^{* *} p<0.05 ;{ }^{* * *} p<0.01$.

Dependent variable: $\Delta \log (\text { Loan Volume })_{i j t}$

(1) (2) (3) (4)

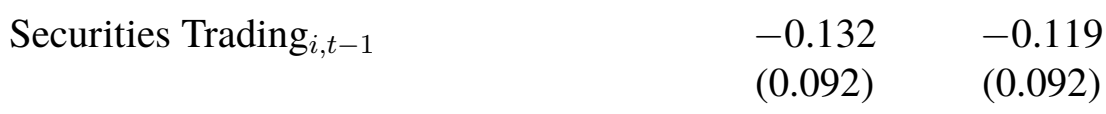

Trading Memberships ${ }_{i}$

Securities Trading ,,$t-1^{*}$ Financial Crisis $\quad-0.818^{* * *}$

$\begin{array}{cc}-0.175^{* * *} & -0.179^{* * *} \\ (0.026) & (0.026)\end{array}$

(0.101)

Securities Trading ${ }_{i, t-1} *$ Financial Stress S $_{t}$

Trading Memberships ${ }_{i}{ }^{*}$ Financial Crisis

$$
\begin{gathered}
-0.154^{* * *} \\
(0.014)
\end{gathered}
$$

Trading Memberships ${ }_{i}{ }^{*}$ Financial Stress $_{t}$

Financial Crisis

$-0.167^{* * *}$

(0.049)

Financial Stress ${ }_{t}$

(0.049)

$\log (\text { Total Assets })_{i, t-1}$

$0.483^{* * *}$

(0.011)

$1.164^{* * *}$

(0.227)

Liquidity Ratio $_{i, t-1}$

$3.753^{* * *}$

(0.497)

Capital Ratio $i, t-1$

$0.110^{* * *}$

(0.024)

Loans-To-Deposits $_{i, t-1}$

$13.825^{\text {*** }}$

0.009

$-0.196^{* * *}$

(0.026)

$$
\begin{gathered}
-0.042^{* * *} \\
(0.004)
\end{gathered}
$$

$\mathrm{ROA}_{i, t-1}$

(1.546)

$-0.212^{* * *}$

(0.047)

(0.009)

$0.482^{* * *}$

(0.011)

$1.225^{* * *}$

(0.227)

$3.647^{\text {*** }}$

(0.501)

$0.119^{* * *}$

(0.024)

$14.532^{* * *}$

(0.501**

$0.501^{* * *}$

0.002

(0.008)

(0.011)

$0.912^{* * *}$

$0.502^{* * *}$

(0.011)

(0.218)

$3.725^{\text {*** }}$

$0.996^{* * *}$

(0.218)

(0.484)

$3.583^{* * *}$

$0.097^{* * *}$

(0.489)

$0.105^{* * *}$

(0.023)

(0.023)

$12.217^{* * *}$

$12.594^{* * *}$

Firm Cluster-Year FE

YES

(1.563)

(1.559)

(1.575)

Bank Country FE

YES

YES

YES

YES

Observations

264,716

YES

YES

YES

Adjusted $\mathrm{R}^{2}$

0.372

264,716

264,716

264,716

0.372

0.373

0.373 
In Figure 3a, we visualize the marginal effect of Trading Memberships for the observed range of values of the Financial Stress Index. ${ }^{7}$ In Figure 3b, we visualize the same effect for Securities Trading. The positive values of the index indicate financial market stress, and negative values indicate financial market relaxation (stabilizing conditions). The marginal effect is downward sloping and statistically significant, with a relatively narrow confidence interval across the whole range of Financial Stress Index values. This supports our earlier interpretation that banks with more extensive securities trading tend to reduce loan supply even under favorable financial market conditions but reduce loan supply even further with increasing financial market stress. In the figure, we highlight the marginal effects for the zero values of the Financial Stress Index, its 2007 to 2009 crisis average, and its 2007 to 2009 crisis peak value.

\section{Figure 3: The Effect of Securities Trading as a Function of Financial Stress}

In this figure, we visualize marginal effects associated with the coefficient estimates reported in columns (2) and (4) of Table 2 for Securities Trading and Trading Memberships, respectively. Marginal effects are computed for a range of values of the Financial Stress Index. The Financial Stress Index is centered on zero. Positive values of the index indicate financial market stress, and negative values indicate financial market relaxation (stabilizing conditions). See Figure 2 for a plot of the time series of the index. During the 2007 to 2009 financial crisis, the index peaked, close to a value of 15, with an average from 2007 to 2009 of approximately 5.55. Shaded areas represent $95 \%$ confidence bands based on marginal effects' standard errors that are derived from the clustered variance-covariance matrix of estimated coefficients reported in Table 2, columns (2) and (4).

a) Marginal Effect of Securities Trading

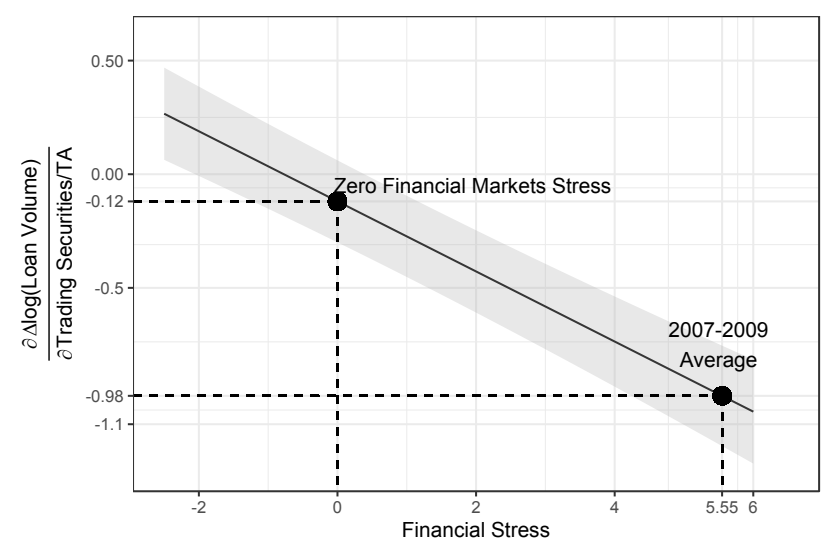

b) Marginal Effect of Trading Memberships

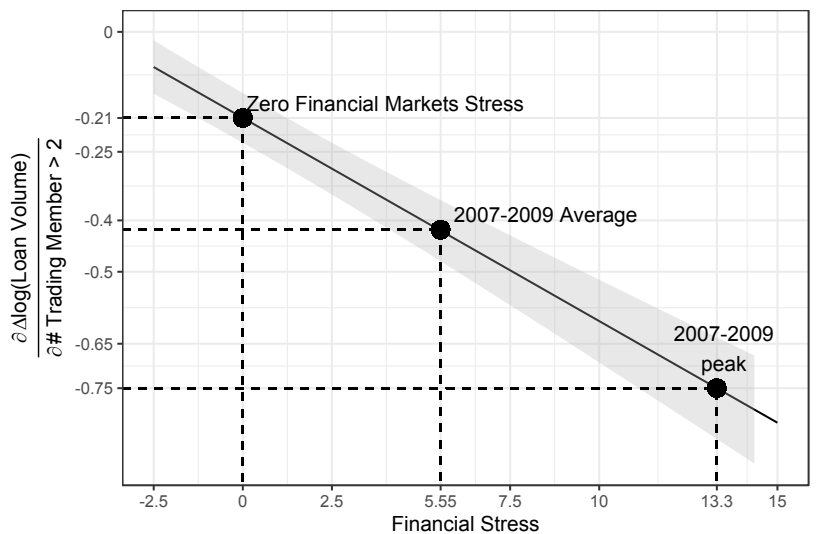

\footnotetext{
${ }^{7}$ See Figure 2
} 
In summary, we find support for the hypothesis that banks with greater securities trading provide fewer loans to non-financial borrowers and reduce loan supply, especially during financial crises. These findings confirm the theoretical predictions of Diamond and Rajan (2011), Shleifer and Vishny (2010), and Boot and Ratnovski (2016).

\subsection{Trading and Foreign Lending}

Home biases in lending and a decline in foreign lending since the 2008 financial crisis are well documented in the literature (Marchetti, 2016). Ivashina and Scharfstein (2010) show that home bias increased during the crisis. Our aim in this section is to contribute to this literature by analyzing the effect of banks' securities trading on foreign lending. We define Foreign Lending as loans granted by a bank to a borrower that is incorporated in a country other than the bank. Thus, we create a dummy variable that equals one if a bank and borrower's countries of incorporation differ and zero otherwise. We also consider the geographic and economic distance between a bank and borrower's countries of incorporation as continuous measures of the degree to which the bank and borrower countries differ. We compute the geographic Distance between the bank and borrower countries using the great-circle distance formula used in physics and navigation. The great-circle distance is the shortest distance between any two points on the surface of a sphere and is computed as

$$
\operatorname{Distance}_{i, j}=r \times \arccos \left(\sin \left(\operatorname{Lat}_{i}\right) \sin \left(\operatorname{Lat}_{j}\right)+\cos \left(\operatorname{Lat}_{i}\right) \cos \left(\operatorname{Lat}_{j}\right) \cos \left(\operatorname{Long}_{i}-\operatorname{Long}_{j}\right)\right)
$$

where $L a t_{i}, L a t_{j}$ and $L o n g_{i}, L o n g_{j}$ are the latitude and longitude, respectively, of the centroids of bank country $i$ and borrower country $j .{ }^{8} r$ is Earth's mean radius in $\mathrm{km}(\approx 6,371 \mathrm{~km}) .{ }^{9}$ Since Distance $_{i, j}$ is heavily skewed, we use the logarithm of Distance $_{i, j}$ in all regressions. If bank and borrower are incorporated in the same country, we set Distance $_{i, j}=1$ instead of using the

\footnotetext{
${ }^{8}$ The centroid of a country is the geometric center of the two-dimensional polygon spanned by the country's borders.

${ }^{9}$ That is $\approx 3,959$ miles.
} 
great-circle distance. ${ }^{10}$ Thus, the logarithm of the geographic distance equals zero whenever the foreign lending dummy equals zero. We proxy for the economic distance between bank and borrower countries using the absolute value of the difference in the KOF Globalisation Index. The index is a measure of the level of globalization of individual countries along economic, social, and political dimensions. ${ }^{11}$

We repeat our estimation of our Equation (1) but augment the regression model with the foreign lending dummy, the geographic distance measure, and the economic distance measure. ${ }^{12}$ In columns (1) to (3) of Table 3, we present the results for the foreign lending dummy, with geographic and economic distance measured in the specification using Trading Memberships. Columns (4) to (6) contain the results using Securities Trading instead. The coefficients associated with foreign lending are consistently negative and statistically significant across all specifications, indicating a rather strong lending home bias among the banks in our sample. The coefficients of interest in this regression specification are the interactions between our trading measures Trading Memberships or Securities Trading and the Foreign Lending variables. The interaction term coefficients are positive and statistically significant for all regression specifications, except for column (6). Thus, banks with

\footnotetext{
${ }^{10}$ This approach simply implies that we assume that the physical distance in $\mathrm{km}$ between bank and borrower is 1 if both are incorporated in the same country.

${ }^{11}$ The KOF Index is computed and published by the Swiss Economic Institute at ETH Zürich. See https:// kof .ethz.ch/en/forecasts-and-indicators/indicators/kof-globalisation-index.html. For details regarding the computation of the index, see Dreher (2006) (the original version of the index) and Gygli, Haelg and Sturm (2018) (the revised version of the index that is used in this paper). Since the most current KOF Globalisation Index is only available until 2015, we augment the values for 2016 for each country using qsimple AR(p) one-year-ahead forecasts, while for each country's time-series, the lag-length $\mathrm{p}$ is selected to minimize the AIC. Using data until 2015 only does not change the results. We show the results for data ranging only until 2015 in Table D.1 in Appendix D

${ }^{12}$ Approximately $65.6 \%$ of all bank-borrower loan connections in our sample can be described as foreign lending. However, many of these loans are granted within the European Economic Area (EEA). The EEA essentially covers the EU plus Switzerland and Norway. Common regulatory frameworks in many areas and an overall comparatively high degree of economic integration lead to a lower risk of foreign lending for EEA banks to EEA borrowers. For example, it is significantly easier to enforce contracts across borders within the EEA than outside the EEA because of the comparatively high degree of harmonization of regulations within the EEA. Thus, the EEA might be seen as a single lending market. If we treat the EEA as if it were one country in our definition of foreign lending, the share of bank-borrower loan connections that imply foreign lending is approximately $49.8 \%$. We repeat our analysis of the connection of securities trading and foreign lending, treating the EEA as a single country. The corresponding results are shown in Table D.2 in Appendix D. While the magnitude of some coefficients changes, the conclusions remain the same as in our main analysis in Table 3.
} 
more extensive trading operations tend to increase their loan supply to foreign markets relative to banks with less extensive trading operations. However, the marginal effects of Trading Memberships and Securities Trading remain negative in most cases. Liu and Pogach (2017) show that when capital is tight during stable economic times, foreign lending comes at the expense of domestic lending. Using the notion that trading banks need to allocate a fixed amount of capital between their trading and lending operations, the results of Liu and Pogach (2017) are consistent with our finding that, ceteris paribus, banks with greater trading operations reduce foreign lending less than domestic lending. We isolate the impact of the 2008 financial crisis on domestic and foreign lending by augmenting the regressions by a three-way interaction term between Financial Crisis dummy, our foreign lending variables, and our trading proxies in Table 4. Most of the three-way interaction terms are negative and statistically significant. The marginal effects show that the effect of foreign lending reverts during financial crisis.

The increase in loan supply to foreign markets by banks with more extensive securities trading may simply reflect a greater degree of internationalization and a stronger specialization in the lending business among banks with large trading operations relative to banks with smaller trading operations. Banks with global lending operations may specialize in providing trade credit to exporters from specific markets. For example, the Spanish bank Banco Santander, which we classify as a trading bank, specializes in providing trade credit to Peruvian export firms (see Paravisini et al. (2017)). De Haas and Van Horen (2012) show that banks generally reduce their loan supply to geographically distant locations. This is consistent with the negative coefficients associated with $\log ($ Distance) and Economic Distance in Table 3. However, De Haas and Van Horen (2012) also show that this effect is counteracted if banks operate foreign subsidiaries or foreign branches or have lending experience in a foreign market. Thus, the positive sign of the interactions between Trading Memberships or Securities Trading and $\log ($ Distance) or Economic Distance may simply reflect a geographically more dispersed branch network of banks with more extensive securities trading relative to banks with less extensive securities trading. Unfortunately, our data do not allow us to directly observe 
Table 3: Is Foreign Lending Affected Differently than Domestic Lending by Securities Trading?

Notes: In this table, we present the results regarding the effect of securities trading on loan supply in foreign lending. The regression setup is as in Equation (1)) but augmented by different measures of distance between bank and borrower. The unit of observation is firm cluster-year. Firm clusters are formed based on a firm's country of incorporation, the two-digit SIC code, and a firm's credit rating, estimated based on the median EBIT interest coverage ratios. Trading Memberships equals one if a bank has more than two trading memberships at securities exchanges and zero otherwise. Securities Trading is the one-year-lagged USD value of a bank's trading account divided by its total assets. Both variables are interacted with the distance measures. Foreign Lending is a dummy variable that equals one if a bank and borrower's countries of incorporation are not the same. Distance is the physical distance between a bank and borrower's countries of incorporation. Economic Distance is the absolute value of the difference in the KOF Globalisation Index of a bank and borrower's countries of incorporation. All regressions include bank-level controls (the logarithm of total assets, return-on-assets, common equity/total assets, cash/total assets, and total loans/total deposits). The results for the bank controls are reported in Table B.2 in Appendix B. Standard errors are clustered at the bank-firm cluster level. Significance levels: ${ }^{*} p<0.1 ;{ }^{* *} p<0.05 ;{ }^{* * *} p<0.01$.

\begin{tabular}{|c|c|c|c|c|c|c|}
\hline & \multicolumn{6}{|c|}{ Dependent Variable: $\Delta \log ($ Loan Volume $)$} \\
\hline & (1) & (2) & (3) & (4) & (5) & (6) \\
\hline Trading Memberships $_{i}$ & $\begin{array}{c}-0.359^{* * *} \\
(0.041)\end{array}$ & $\begin{array}{l}-0.331^{* * *} \\
(0.040)\end{array}$ & $\begin{array}{l}-0.233^{* * *} \\
(0.031)\end{array}$ & & & \\
\hline Securities Trading ${ }_{i, t-1}$ & & & & $\begin{array}{l}-0.669^{* * *} \\
(0.149)\end{array}$ & $\begin{array}{c}-0.729^{* * *} \\
(0.148)\end{array}$ & $\begin{array}{c}-0.198^{*} \\
(0.114)\end{array}$ \\
\hline Foreign Lending & $\begin{array}{c}-1.485^{* * *} \\
(0.033)\end{array}$ & & & $\begin{array}{l}-1.511^{* * *} \\
(0.034)\end{array}$ & & \\
\hline $\log ($ Distance $)$ & & $\begin{array}{l}-0.175^{* * *} \\
(0.004)\end{array}$ & & & $\begin{array}{l}-0.184^{* * *} \\
(0.004)\end{array}$ & \\
\hline Economic Distance & & & $\begin{array}{l}-0.062^{* * *} \\
(0.002)\end{array}$ & & & $\begin{array}{c}-0.059^{* * *} \\
(0.002)\end{array}$ \\
\hline Trading Memberships ${ }_{i}{ }^{*}$ Foreign Lending & $\begin{array}{l}0.406^{* * *} \\
(0.042)\end{array}$ & & & & & \\
\hline Trading Memberships ${ }_{i}{ }^{*} \log ($ Distance $)$ & & $\begin{array}{c}0.045^{* * *} \\
(0.005)\end{array}$ & & & & \\
\hline Trading Memberships ${ }_{i}{ }^{*}$ Economic Distance & & & $\begin{array}{c}0.009^{* * *} \\
(0.002)\end{array}$ & & & \\
\hline Securities Trading ${ }_{i, t-1} *$ Foreign Lending & & & & $\begin{array}{l}1.456^{* * *} \\
(0.152)\end{array}$ & & \\
\hline Securities Trading ${ }_{i, t-1} * \log ($ Distance $)$ & & & & & $\begin{array}{c}0.194^{* * *} \\
(0.018)\end{array}$ & \\
\hline Securities Trading ${ }_{i, t-1} *$ Economic Distance & & & & & & $\begin{array}{c}0.011 \\
(0.009)\end{array}$ \\
\hline Observations & 267,326 & 267,326 & 266,257 & 267,326 & 267,326 & 266,257 \\
\hline Adjusted $\mathrm{R}^{2}$ & 0.413 & 0.416 & 0.386 & 0.413 & 0.416 & 0.385 \\
\hline Bank Controls & YES & YES & YES & YES & YES & YES \\
\hline Firm Cluster-Year FE & YES & YES & YES & YES & YES & YES \\
\hline Bank Country-Year FE & YES & YES & YES & YES & YES & YES \\
\hline
\end{tabular}


Table 4: Is Foreign Lending Affected Differently than Domestic Lending by Securities Trading? - Crisis Impact

Notes: In this table, we present the results regarding the effect of securities trading on loan supply in foreign lending. The regression setup is as in Equation (1)) but augmented by different measures of distance between bank and borrower. The unit of observation is firm cluster-year. Firm clusters are formed based on a firm's country of incorporation, the two-digit SIC code, and a firm's credit rating, estimated based on the median EBIT interest coverage ratios. Trading Memberships equals one if a bank has more than two trading memberships at securities exchanges and zero otherwise. Securities Trading is the one-year-lagged USD value of a bank's trading account divided by its total assets. Both variables are interacted with the distance measures. Foreign Lending is a dummy variable that equals one if a bank and borrower's countries of incorporation are not the same. Distance is the physical distance between a bank and borrower's countries of incorporation. Economic Distance is the absolute value of the difference in the KOF Globalisation Index of a bank and borrower's countries of incorporation. Financial Crisis is dummy variable that equals one if financial stress is above 5 and zero otherwise. All regressions include bank-level controls (the logarithm of total assets, return-on-assets, common equity/total assets, cash/total assets, and total loans/total deposits). The results for the bank controls are reported in Table B.3 in Appendix B. Standard errors are clustered at the bank-firm cluster level. Significance levels: ${ }^{*} p<0.1 ;{ }^{* *} p<0.05 ;{ }^{* * *} p<0.01$.

\begin{tabular}{|c|c|c|c|c|c|c|}
\hline & \multicolumn{6}{|c|}{ Dependent Variable: $\Delta \log ($ Loan Volume $)$} \\
\hline & $(1)$ & $(2)$ & $(3)$ & $(4)$ & $(5)$ & $(6)$ \\
\hline Trading Member M $_{i}$ & $\begin{array}{c}-0.281^{* * *} \\
(0.041)\end{array}$ & $\begin{array}{c}-0.242^{* * *} \\
(0.041)\end{array}$ & $\begin{array}{c}-0.167^{* * *} \\
(0.031)\end{array}$ & & & \\
\hline Securities Trading $_{i, t-1}$ & & & & $\begin{array}{c}-0.525^{* * *} \\
(0.151)\end{array}$ & $\begin{array}{c}-0.596^{* * *} \\
(0.149)\end{array}$ & $\begin{array}{l}-0.025 \\
(0.106)\end{array}$ \\
\hline Trading Member $_{i}{ }^{*}$ Foreign Lending & $\begin{array}{c}0.399^{* * *} \\
(0.043)\end{array}$ & & & & & \\
\hline Trading Member $_{i}{ }^{*} \log ($ Distance $)$ & & $\begin{array}{c}0.042^{* * *} \\
(0.005)\end{array}$ & & & & \\
\hline Trading Member $_{i} *$ Economic Distance & & & $\begin{array}{c}0.010^{* * *} \\
(0.003)\end{array}$ & & & \\
\hline Trading Member $_{i} *$ Financial Crisis & $\begin{array}{c}-0.208^{* * *} \\
(0.032)\end{array}$ & $\begin{array}{c}-0.215^{* * *} \\
(0.032)\end{array}$ & $\begin{array}{c}-0.195^{* * *} \\
(0.022)\end{array}$ & & & \\
\hline Securities Trading $\operatorname{lit-1} *$ Foreign Lending & & & & $\begin{array}{l}1.322^{* * *} \\
(0.159)\end{array}$ & & \\
\hline Securities Trading ${ }_{i, t-1} * \log ($ Distance $)$ & & & & & $\begin{array}{c}0.178^{* * *} \\
(0.019)\end{array}$ & \\
\hline Securities Trading ${ }_{i, t-1} *$ Economic Distance & & & & & & $\begin{array}{c}0.009 \\
(0.009)\end{array}$ \\
\hline Securities Trading $_{i, t-1} *$ Financial Crisis & & & & $\begin{array}{c}-0.369^{* * *} \\
(0.123)\end{array}$ & $\begin{array}{c}-0.333^{* * *} \\
(0.122)\end{array}$ & $\begin{array}{c}-0.490^{* * *} \\
(0.083)\end{array}$ \\
\hline Trading Member $_{i}{ }^{*}$ Foreign Lending*Financial Crisis & $\begin{array}{l}-0.048 \\
(0.037)\end{array}$ & & & & & \\
\hline Trading Member $_{i}{ }^{*} \log ($ Distance $) *$ Financial Crisis & & $\begin{array}{l}-0.005 \\
(0.004)\end{array}$ & & & & \\
\hline Trading Member ${ }_{i}^{*}$ Economic Distance*Financial Crisis & & & $\begin{array}{c}-0.006^{* *} \\
(0.002)\end{array}$ & & & \\
\hline Securities Trading $\operatorname{lit}_{i, 1} *$ Foreign Lending*Financial Crisis & & & & $\begin{array}{c}-0.446^{* * *} \\
(0.141)\end{array}$ & & \\
\hline Securities Trading ${ }_{i, t-1} * \log ($ Distance $) *$ Financial Crisis & & & & & $\begin{array}{c}-0.061^{* * *} \\
(0.017)\end{array}$ & \\
\hline Securities Trading $\operatorname{Tit-1} *$ Economic Distance*Financial Crisis & & & & & & $\begin{array}{c}-0.026^{* * *} \\
(0.009)\end{array}$ \\
\hline Observations & 264,716 & 264,716 & 263,691 & 264,716 & 264,716 & 263,691 \\
\hline Adjusted $R^{2}$ & 0.410 & 0.413 & 0.383 & 0.409 & 0.412 & 0.382 \\
\hline Bank Controls & YES & YES & YES & YES & YES & YES \\
\hline Firm Cluster-Year FE & YES & YES & YES & YES & YES & YES \\
\hline Bank Country FE & YES & YES & YES & YES & YES & YES \\
\hline
\end{tabular}


the branch networks of the banks in our sample. However, LPC DealScan does report some branch information for loans in our sample in addition to the lender name. For example, for some loans granted by BNP Paribas, DealScan reports "BNP Paribas Singapore Branch" as the lender name. Thus, for each loan in our sample for which we have some indication of the specific branch that granted the loan, we hand collect the branch country and use the great-circle distance formula to compute the geographic distance between the branch country and the borrower country. ${ }^{13}$ While this is a rather imprecise measure of a bank's branch network, it may provide us with some general insight regarding the degree of geographic dispersion of a bank's lending business. We report the average distances between the bank country and the borrower country on the one hand and the bank branch country and the borrower country on the other hand in Table 5. We focus on the Trading Memberships dummy variable to have a clear dichotomous separation of banks with more extensive securities trading and less extensive securities trading. We find that for banks with more extensive securities trading, the average geographic distance between the bank and the borrower is larger than the distance between the branch and the borrower. Thus, banks use foreign branches to service foreign customers. Additionally, we find that the average geographic distance between the branch and borrower is lower for banks with more extensive securities trading than for banks with less extensive securities trading. This indicates a greater geographic dispersion of the lending operations and thus a higher degree of internationalization of banks with more extensive securities trading. Hence, consistent with the results in De Haas and Van Horen (2012), the increased loan supply of banks with more extensive securities trading to foreign markets seems to be driven by the greater geographic dispersion of the lending operations of these banks.

\footnotetext{
${ }^{13}$ Note that in many cases, the bank country, branch country, and borrower country are different. For example, we observe loans granted by BNP Paribas to borrowers in Malaysia or the Philippines via the Singapore Branch of BNP Paribas.
} 
Table 5: Do Trading Banks Have Geographically More Dispersed Lending Operations than Non-Trading Banks?

Notes: In this table, we report the average geographic distance between bank country and borrower country for banks with more and less extensive securities trading. Trading Memberships $>2$ indicates banks with more than two trading memberships at securities exchanges and thus indicates more extensive securities trading. \# Trading Memberships $\leq 2$ indicates the opposite. Avg. Distance Bank is the mean value of the logarithm of the geographic distance between the bank country and the borrower country. Avg. Distance Branch is the mean value of the logarithm of the geographic distance between the bank branch country and the borrower country. We report significance levels for two-sided $t$-tests of the mean difference, allowing for unequal sample variance as: ${ }^{*} p<0.1 ;{ }^{* *} p<0.05 ;{ }^{* * *} p<0.01$.

\begin{tabular}{llll}
\hline \hline & \# Trading Memberships $>2$ & \# Trading Memberships $\leq 2$ & Difference \\
\hline Avg. Distance Bank & 4.813 & 4.027 & $0.786^{* * *}$ \\
Avg. Distance Branch & 3.271 & 3.546 & $-0.274^{* * *}$ \\
\hline Difference & $1.541^{* * *}$ & $0.481^{* * *}$ & \\
\hline \hline
\end{tabular}

\subsection{Does Financial Market Depth Matter?}

One of the key propositions in Boot and Ratnovski (2016) is that banks increase trading at the expense of relationship banking activities, such as lending, as financial markets become deeper. Boot and Ratnovski (2016) argue that bank lending involves building relationships with customers and requires gathering private information about borrowers to gauge creditworthiness. On the other hand, securities trading does not rely on private information. Deeper financial markets yield greater trading opportunities and allow banks to conduct larger trades. Therefore, banks may choose to allocate more resources to securities trading operations at the expense of their lending business as financial market depth increases.

We augment our regressions with the IMF's country-level financial market depth index. ${ }^{14}$ We include the index in our regression in Equations (1) and (3) and interact it with Securities Trading and the Trading Memberships dummy. All of these regression specifications include bank country fixed effects. Thus, the estimated coefficients can be interpreted as the effect of the within-bank

\footnotetext{
${ }^{14}$ The financial market depth index is a sub-index of the financial development index family. The financial market depth index aggregates data on a country's stock market capitalization divided by GDP, stocks traded divided by GDP, international debt securities of the government divided by GDP, and total debt securities of financial and non-financial firms divided by GDP. For further details regarding the data, coverage, and methodology of the Financial Development Index and its sub-indices, see Svirydzenka (2016). We report summary statistics for the financial market depth index per bank country in Table A.3 in Appendix A.
} 
country variation in financial market depth.

We report the results in columns (1) and (2) in Table 6. The individual effects of Securities Trading and Trading Memberships are positive and significant, while the corresponding interaction effects with the financial market depth index are negative and significant. Thus, the sign of marginal effects associated with Securities Trading and the Trading Memberships dummy depends on the specific value of the financial market depth index. For low levels of financial market depth, the marginal effects associated with Securities Trading and Trading Memberships are positive. However, as financial markets become deeper, the marginal effects decrease and eventually become negative, as indicated by the negative sign on the coefficient of the interaction effects. This suggests that banks with more extensive securities trading reduce loan supply more as the financial markets in their home countries become deeper. 


\section{Table 6: Financial Market Depth}

Notes: In this table, we present the results regarding the effect of securities trading on loan supply moderated by financial market depth. The regression specification is the same in Equations (1) and (3), augmented by the financial market depth index and relevant interactions. The unit of observation is firm cluster-year. Firm clusters are formed based on a firm's country of incorporation, the two-digit SIC code, and a firm's credit rating, estimated based on the median EBIT interest coverage ratios. Trading Memberships equals one if a bank has more than two trading memberships at securities exchanges and zero otherwise. Securities Trading is the one-year-lagged USD value of a bank's trading account divided by its total assets. Financial stress is the value of the Financial Stress Indicator as provided by the US OFR for a bank's country of incorporation. Financial Crisis is dummy variable that equals one if financial stress is above 5 and zero otherwise. Financial Market Depth (Fin. Markets Depth) is the IMF's financial market depth index. All regressions include bank-level controls (the logarithm of total assets, return-on-assets, common equity/total assets, cash/total assets, and total loans/total deposits). The results for the bank controls are reported in Table B.4 in Appendix B. Standard errors are clustered at the bank-firm cluster level. Significance levels: ${ }^{*} p<0.1 ;{ }^{* *} p<0.05 ;{ }^{* * *} p<0.01$.

\begin{tabular}{|c|c|c|c|c|}
\hline & \multicolumn{4}{|c|}{ Dependent variable: $\Delta \log (\text { Loan Volume })_{j, i, t}$} \\
\hline & (1) & (2) & (3) & (4) \\
\hline Securities Trading $g_{i, t-1}$ & $\begin{array}{c}3.339^{* * *} \\
(0.501)\end{array}$ & & $\begin{array}{c}3.578^{* * *} \\
(0.515)\end{array}$ & \\
\hline Trading Memberships $s_{i}$ & & $\begin{array}{c}0.161 \\
(0.116)\end{array}$ & & $\begin{array}{l}0.274^{* *} \\
(0.120)\end{array}$ \\
\hline Financial Market Depth ${ }_{i, t-1}$ & $\begin{array}{l}1.248^{* * *} \\
(0.110)\end{array}$ & $\begin{array}{c}0.921^{* * *} \\
(0.106)\end{array}$ & $\begin{array}{c}1.387^{* * *} \\
(0.113)\end{array}$ & $\begin{array}{c}1.076^{* * *} \\
(0.111)\end{array}$ \\
\hline Securities Trading ${ }_{i, t-1} *$ Fin. Markets Depth $h_{i, t-1}$ & $\begin{array}{c}-3.824^{* * *} \\
(0.543)\end{array}$ & & $\begin{array}{c}-4.016^{* * *} \\
(0.555)\end{array}$ & \\
\hline Trading Memberships $_{i}{ }^{*}$ Fin. Markets Depth D $_{i, t-1}$ & & $\begin{array}{c}-0.384^{* * *} \\
(0.128)\end{array}$ & & $\begin{array}{c}-0.491^{* * *} \\
(0.131)\end{array}$ \\
\hline Financial Crisis & & & $\begin{array}{l}-0.085 \\
(0.166)\end{array}$ & $\begin{array}{l}-0.141 \\
(0.136)\end{array}$ \\
\hline Fin. Markets Depth ${ }_{i, t-1}{ }^{*}$ Financial Crisis & & & $\begin{array}{c}0.033 \\
(0.197)\end{array}$ & $\begin{array}{c}0.010 \\
(0.163)\end{array}$ \\
\hline Securities $\operatorname{Trading}_{i, t-1} *$ Financial Crisis & & & $\begin{array}{l}-0.273 \\
(0.832)\end{array}$ & \\
\hline Trading Memberships ${ }_{i}{ }^{*}$ Financial Crisis & & & & $\begin{array}{c}0.297 \\
(0.215)\end{array}$ \\
\hline Fin. Markets Depth ${ }_{i, t-1} *$ Financial Crisis & & & $\begin{array}{l}-0.080 \\
(0.194)\end{array}$ & $\begin{array}{l}-0.084 \\
(0.160)\end{array}$ \\
\hline Securities Trading $_{i, t-1} *$ Fin. Markets Depth*Financial Crisis & & & $\begin{array}{l}-0.867 \\
(0.965)\end{array}$ & \\
\hline Trading Memberships $_{i} *$ Fin. Markets Depth ${ }_{i, t-1} *$ Financial Crisis & & & & $\begin{array}{c}-0.613^{* *} \\
(0.257)\end{array}$ \\
\hline Observations & 267,326 & 267,326 & 264,716 & 264,716 \\
\hline Adjusted $\mathrm{R}^{2}$ & 0.371 & 0.371 & 0.373 & 0.373 \\
\hline Bank Controls & YES & YES & YES & YES \\
\hline Firm Cluster-Year FE & YES & YES & YES & YES \\
\hline Bank Country FE & YES & YES & YES & YES \\
\hline
\end{tabular}

We visualize the marginal effects associated with Securities Trading and the Trading Memberships 


\section{Figure 4: Marginal Effect}

Notes: In this figure, we show marginal effects associated with the coefficient estimates reported in Table 6, columns (3) and (4) for Securities Trading and Trading Memberships, respectively. The marginal effects are computed for a range values of the financial market depth index. Shaded areas represent $95 \%$ confidence bands based on marginal effects' standard errors. Standard errors of the marginal effects are reported in brackets below the marginal effects. All standard errors are derived from the clustered variance-covariance matrix of estimated coefficients associated with Table 6, columns (3) and (4).

a) Marginal Effect of Securities Trading

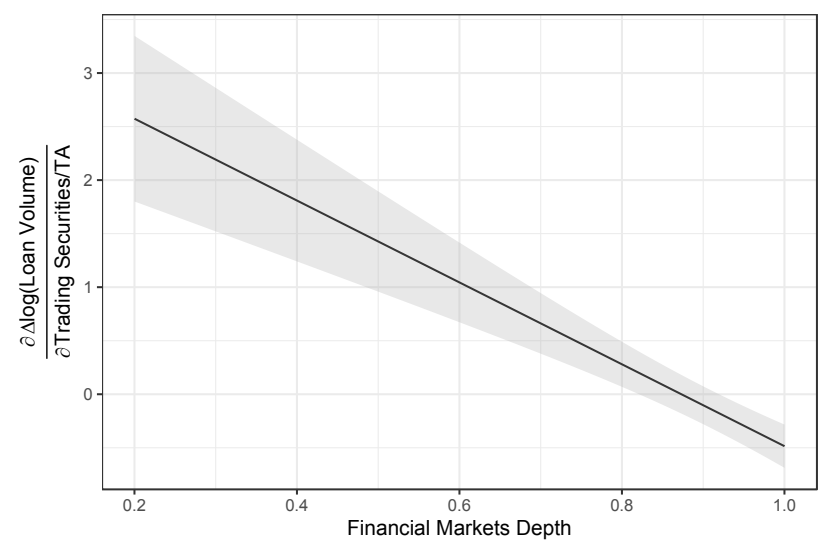

b) Marginal Effect of Trading Memberships

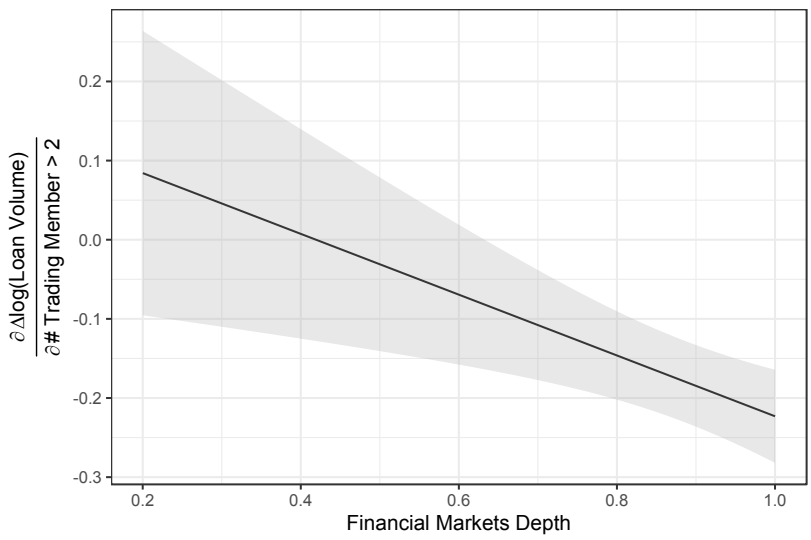

dummy in Figure 4. The left panel shows that for countries with deep financial markets, the marginal effect associated with Securities Trading is negative, while it is positive for countries with less deep financial markets. The cutoff point at which the marginal effect becomes positive is approximately 0.87 for financial market depth. The right panel shows that for countries with deep financial markets, the marginal effect associated with Trading Memberships is negative except for very low values of financial market depth. This is in line with the rationale suggested by Boot and Ratnovski (2016), whereby banks tend to re-allocate increasing resources from lending to securities trading as financial markets become deeper. The marginal effects associated with the Trading Memberships dummy are negative even for countries with relatively low financial market depth.

Additionally, in Table 7, we report the marginal effects associated with Securities Trading and the Trading Memberships dummy at means of the financial market depth index for a number of example countries with rather high and rather low values of financial market depth. 
Table 7: Marginal Effects and Financial Market Depth

Notes: In this table, we present the marginal effects associated with the coefficient estimates reported in Table 6, columns (1) and (2) for Securities Trading and Trading Memberships respectively. Each marginal effect is computed at the time-series mean of the financial market depth index for the relevant country for the sample period from 2003 to 2016. Standard errors of the marginal effects are reported in brackets below the marginal effects. All standard errors are derived from the clustered variance-covariance matrix of estimated coefficients associated with Table 6, columns (1) and (2). Significance levels: ${ }^{*} p<0.1 ;{ }^{* *} p<0.05 ;{ }^{* * *} p<0.01$.

\begin{tabular}{|c|c|c|c|}
\hline \multirow[t]{2}{*}{ Country } & \multirow[t]{2}{*}{ Financial Market Depth } & \multicolumn{2}{|c|}{ Marginal Effect at country mean } \\
\hline & & Securities Trading & Trading Memberships \\
\hline US & 0.983 & $\begin{array}{c}-0.420^{* * *} \\
(0.099)\end{array}$ & $\begin{array}{c}-0.217^{* * *} \\
(0.029)\end{array}$ \\
\hline UK & 0.979 & $\begin{array}{c}-0.405^{* * *} \\
(0.098)\end{array}$ & $\begin{array}{c}-0.215^{* * *} \\
(0.029)\end{array}$ \\
\hline The Netherlands & 0.923 & $\begin{array}{c}-0.191^{* *} \\
(0.090) \\
\end{array}$ & $\begin{array}{c}-0.193^{* * *} \\
(0.027)\end{array}$ \\
\hline All Countries' Average & 0.870 & $\begin{array}{c}0.012 \\
(0.092) \\
\end{array}$ & $\begin{array}{c}-0.173^{* * *} \\
(0.026) \\
\end{array}$ \\
\hline Japan & 0.733 & $\begin{array}{c}0.536^{* * *} \\
(0.131)\end{array}$ & $\begin{array}{c}-0.121^{* * *} \\
(0.033)\end{array}$ \\
\hline Germany & 0.690 & $\begin{array}{c}0.700^{* * *} \\
(0.149)\end{array}$ & $\begin{array}{c}-0.104^{* * *} \\
(0.036)\end{array}$ \\
\hline Italy & 0.637 & $\begin{array}{c}0.903^{* * *} \\
(0.172)\end{array}$ & $\begin{array}{c}-0.084^{* * *} \\
(0.041)\end{array}$ \\
\hline
\end{tabular}

In columns (3) and (4) of Table 6, we focus on the financial crisis period by additionally interacting Securities Trading and Trading Memberships with financial market depth and our financial crisis dummy. We visualize the corresponding marginal effects in Figure 5. Qualitatively, the results are the same as those presented in Figure 4. For low values of the financial market depth index, the marginal effects during periods of financial stress and calm are not significantly different. If one recalls that we reported in Figure 3 that the loan supply from banks with greater securities trading declines even further during periods of financial market stress, the results in Figure 5 suggest that this effect is primarily driven by banks located in countries with deep financial markets. Regarding the marginal effects associated with the Trading Memberships dummy, the difference between effects during financial crisis and calm periods is statistically significant only for financial market depth 
Figure 5: Marginal Effects and Crisis Periods

Notes: In this figure, we depict the marginal effects associated with the coefficient estimates reported in Table 6, columns (3) and (4) for Securities Trading and Trading Memberships, respectively. Marginal effects are computed for a range of values of the financial market depth index. Each marginal effect is shown if the financial crisis dummy equals one and if it equals zero. Shaded areas represent 95\% confidence bands based on marginal effects' standard errors. Standard errors of the marginal effects are reported in brackets below the marginal effects. All standard errors are derived from the clustered variance-covariance matrix of estimated coefficients associated with Table 6, columns (3) and (4).

a) Marginal Effect of Securities Trading

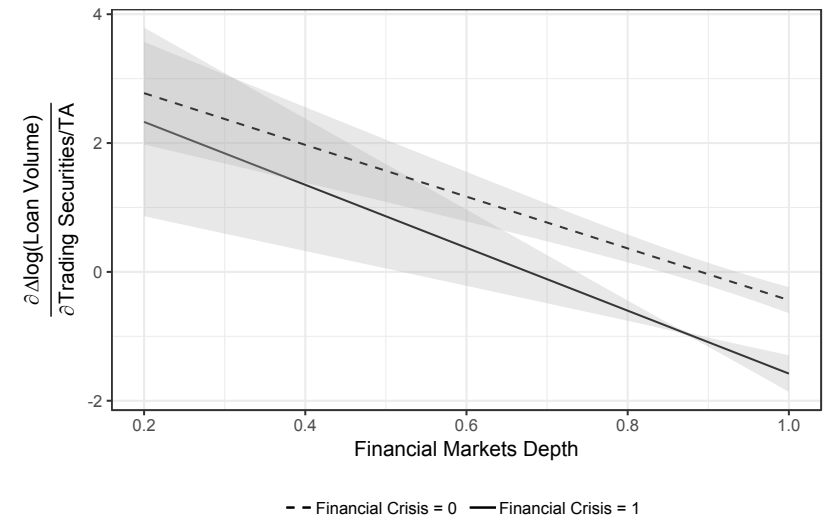

b) Marginal Effect of Trading Memberships

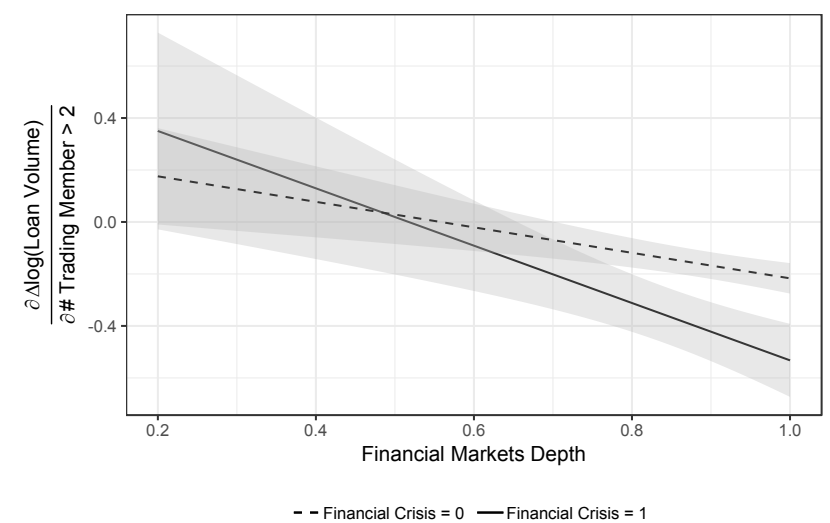

index values greater than 0.63. Regarding the marginal effects associated with Securities Trading, the difference between effects during financial crisis and calm periods becomes statistically significant for financial market depth index values greater than 0.4. The steeper slopes of the lines indicating the marginal effects during financial crisis indicate that financial market depth becomes more important for lending during periods of crisis than during calm periods.

Overall, the results in Table 6 suggest that the negative relationship between loan supply and securities trading that we report in the previous sections is, to a large extent, driven by banks located in countries with deep financial markets. We thus confirm the key propositions of Boot and Ratnovski (2016). Moreover, we show that the strength of the response of trading banks' loan supply to periods of financial crisis is influenced by financial market depth. This suggests that the fire sale hypothesis proposed in Shleifer and Vishny (2010) and Diamond and Rajan (2011) is more pronounced for banks located in countries with deep financial markets. 


\subsection{Loan Pricing}

Results in the previous sections show that banks with more extensive securities trading tend to reduce their loan supply. In this section, we analyze whether there are significant the differences in loan pricing between banks with more and less securities trading. Higher loan prices translate into higher cost of capital for borrowers. Since investments will have to at least earn their cost of capital, increasing loan prices can hamper investments. Following an approach similar to Acharya et al. (2018), we analyze loan pricing by using the change in average loan prices paid by firm clusters as the dependent variable. We measure loan prices as the All-in Spread drawn, which equals the total (fees plus interest) annual spread paid over LIBOR drawn from the loan. In particular, we calculate All-in Spread drawn $=$ Upfront fee + Annual fee + Utilization Fee + Interest Spread over LIBOR . Thus, the All-in Spread drawn represents the cost of financing for the relevant borrower (see, e.g., Ivashina (2005)).

We present the results of this analysis in Table 8. Columns (1) and (3) contain the results for Trading Memberships and Securities Trading without interaction with the Financial Stress or Financial Crisis proxy. The remaining columns contain the results when also including these interactions. Our results indicate that all of our sample banks increase loan prices during periods of increasing financial stress. Moreover, we find that banks with more extensive securities trading charge their borrowers higher prices for loans. A one-standard-deviation increase in Securities Trading results in an approximately 23 bps increase in the average spread. Similarly, we find that banks with more than two trading memberships increase spreads by, on average, 88 bps. However, the interaction between the two effects is statistically insignificant. This indicates that while banks with more extensive securities trading tend to charge higher prices during stable times, they do not behave differently in terms of their loan pricing than banks with less extensive securities trading when stress accumulates in financial markets.

Columns (5) and (6) contain results using our Financial Crisis dummy instead of the Financial Stress Index. Recalling that the Financial Crisis dummy equals one if the Financial Stress Index 
takes values greater than five and zero otherwise, the specification in columns (5) and (6) captures the effect around the peak of the 2008 financial crisis. Significance of the interaction between Financial Crisis and Trading Memberships or Securities Trading would imply that only peak of 2008 financial crisis mattered for differences in loan pricing. Interestingly, the marginal effect associated with Trading Memberships or Securities Trading becomes negative in this specification, indicating a rather sharp decline in loan prices for banks with more extensive securities trading around the peak of the 2008 financial crisis. The consistently positive and statistically significant coefficients associated with the Financial Stress Index and the Financial Crisis dummy across all regression specifications indicate that loan financing becomes more expansive as stress accumulates in financial markets. As financial stress increases, it becomes more difficult for firms to obtain market financing, allowing banks to charge higher prices for loans. Erel et al. (2011) show that only the highest quality borrowers retain the ability to obtain market financing during periods of extreme financial stress. Thus, higher loan prices may also reflect higher risk premiums paid by lower quality borrowers. The marginal effects associated with the Financial Crisis dummy are positive in columns (5) and (6), even after considering interaction terms with Trading Memberships or Securities Trading. Thus, while all sample banks increased loan prices during the 2008 financial crisis, banks with more extensive securities trading increased loan prices less during that time. Recall that our results in the previous section show that banks with more extensive securities trading reduce their loan supply more than banks with less extensive securities trading during periods of financial stress. In light of this finding, our result that banks with more extensive securities trading increase loan prices less than banks with less extensive securities trading suggests that these banks may attempt to retain remaining corporate clients during such periods. 


\section{Table 8: The Effect of Securities Trading on Loan Pricing}

Notes: In this table, we present the results regarding the effect of securities trading on loan pricing. The regression specification is similar to the specification presented in Equations (1) and (3). The unit of observation is the firm cluster-year. The dependent variable is the change in logarithms in All-in Spread drawn, where we calculate All-in Spread drawn $=$ Upfront fee + Annual fee + Utilization Fee + Interest Spread over LIBOR. Firm clusters are formed based on a firm's country of incorporation, the two-digit SIC code, and a firm's credit rating, estimated based on the median EBIT interest coverage ratios. Trading Memberships equals one if a bank has more than two trading memberships at securities exchanges and zero otherwise. Securities Trading is the one-year-lagged USD value of a bank's trading account divided by its total assets. Financial stress is the value of the Financial Stress Indicator as provided by the US OFR for a bank's country of incorporation. Financial Crisis is dummy variable that equals one if financial stress is above 5 and zero otherwise. All regressions include bank-level controls (the logarithm of total assets, return-on-assets, common equity/total assets, cash/total assets, and total loans/total deposits). The results for the bank controls are reported in Table B.5 in Appendix B. Standard errors are clustered at the bank-firm cluster level. Significance levels: ${ }^{*} p<0.1 ;{ }^{* *} p<0.05 ;{ }^{* * *} p<0.01$.

\begin{tabular}{|c|c|c|c|c|c|c|}
\hline & \multicolumn{6}{|c|}{ Dependent variable: $\Delta(\text { All-in Spread Drawn })_{i j t}$} \\
\hline & (1) & (2) & (3) & (4) & $(5)$ & (6) \\
\hline Securities Trading $_{i, t-1}$ & $\begin{array}{c}1.962^{*} \\
(1.065)\end{array}$ & $\begin{array}{c}1.822^{*} \\
(1.070)\end{array}$ & & & $\begin{array}{c}3.090^{* * *} \\
(1.097)\end{array}$ & \\
\hline Trading Memberships $_{i}$ & & & $\begin{array}{c}0.880^{* * *} \\
(0.202)\end{array}$ & $\begin{array}{c}0.890^{* * *} \\
(0.203)\end{array}$ & & $\begin{array}{c}1.047^{* * *} \\
(0.216)\end{array}$ \\
\hline Securities Trading ${ }_{i, t-1} *$ Financial Stress & & $\begin{array}{c}0.458 \\
(0.497)\end{array}$ & & & & \\
\hline Trading Memberships ${ }_{i}{ }^{*}$ Financial Stress & & & & $\begin{array}{l}-0.098 \\
(0.126)\end{array}$ & & \\
\hline Securities Trading ${ }_{i, t-1} *$ Financial Crisis & & & & & $\begin{array}{c}-14.473^{* * *} \\
(4.760)\end{array}$ & \\
\hline Trading Memberships ${ }_{i} *$ Financial Crisis & & & & & & $\begin{array}{c}-3.117^{* *} \\
(1.248)\end{array}$ \\
\hline Financial Stress & $\begin{array}{c}0.595^{* * *} \\
(0.223)\end{array}$ & $\begin{array}{l}0.488^{* *} \\
(0.245)\end{array}$ & $\begin{array}{c}0.625^{* * *} \\
(0.222)\end{array}$ & $\begin{array}{c}0.701^{* * *} \\
(0.237)\end{array}$ & & \\
\hline Financial Crisis & & & & & $\begin{array}{c}7.609^{* * *} \\
(2.293)\end{array}$ & $\begin{array}{c}6.664^{* * *} \\
(2.224) \\
\end{array}$ \\
\hline Bank Controls & YES & YES & YES & YES & YES & YES \\
\hline Firm Cluster-Year FE & YES & YES & YES & YES & YES & YES \\
\hline Bank Country FE & YES & YES & YES & YES & YES & YES \\
\hline Observations & 200,570 & 200,570 & 200,570 & 200,570 & 200,570 & 200,570 \\
\hline Adjusted $\mathrm{R}^{2}$ & 0.265 & 0.265 & 0.265 & 0.265 & 0.265 & 0.265 \\
\hline
\end{tabular}

\section{Borrower-level Analysis}

\subsection{Empirical Approach}

The results in the previous sections indicate that banks with greater securities trading supply fewer loans to non-financial borrowers than banks with less securities trading, even when considering 
the same borrower in the same year. The within-borrower regression specifications in the previous sections do not allow us to assess the effect of banks' securities trading on the aggregate borrowing at the borrower level, as this includes loan flows from ending and new lending relationships. However, borrowers may have the possibility to compensate for lower loan supply from banks with more extensive securities trading with loans from banks with less extensive securities trading or by obtaining market financing. Therefore, the regressions in the previous sections capture only the intensive margin but not the extensive margin of the effect of banks' trading on lending. If loan flows from ending and new lending relationships represent an important margin of adjustment, then the overall strength of the effect of banks' securities trading on lending should be estimated at the borrower level. We estimate the extensive margin following an approach similar to Khwaja and Mian (2008) and Cingano et al. (2016) and implement the following model:

$$
\begin{aligned}
\Delta \text { Aggregate Loans }_{j t}=\lambda \overline{\text { Exposure }}_{j t} & +\hat{\gamma}_{j t}+\boldsymbol{\Psi} \mathbf{F}_{\mathbf{j t}-\mathbf{1}}+ \\
& +\alpha_{j}+\alpha_{\text {Country } \times \text { Industry } \times \text { Year }}+\alpha_{\text {Foreign Loans } \times Y e a r}+\varepsilon_{j t}
\end{aligned}
$$

$\mathbf{F}_{\mathbf{j t - 1}}$ is a matrix of borrower control variables. $\alpha_{j}$ denotes borrower fixed effects. $\alpha_{\text {Countr } y \times \text { Industry } \times \text { Year }}$ and $\alpha_{\text {Foreign Loans } \times \text { Year }}$ represent borrower country $\times$ industry $\times$ year fixed effects and foreign loans $\times$ year fixed effects. $\hat{\gamma}$ is the estimated loan demand, obtained as the fixed effects coefficients from Equations (1) and (3). Since Equations (1) and (3) are estimated via the within-estimator, we do not directly obtain estimates for the fixed effects coefficients. Instead, we obtain the fixed effects as the solution to the equation $D \hat{\gamma}_{j t}=(I-Q)(\Delta \log (\operatorname{LoanV}$ olume $)-\beta X)$, where $\mathrm{X}$ and $\beta$ are vectors containing all right-hand-side variables and coefficients from Equation (1). $I$ is the identity matrix, $\mathrm{Q}$ is a standard projection matrix for the within-estimator, and D is a matrix containing dummies defining the firm cluster $\times$ year fixed effects. As $\hat{\gamma}_{j t}$ is the only unknown quantity in this equation, we can solve it for $\hat{\gamma}_{j t}$. Cingano et al. (2016) and Bonaccorsi di Patti and Sette (2012) show that including $\hat{\gamma}_{j t}$ in Equation (4) corrects for potential biases in the model due to potential 
correlation between the $\overline{\text { Exposure }}_{j t}$ and loan demand. The coefficient of interest in Equation (4) is $\lambda$, capturing the extensive margin of the effect of a bank's securities trading on loan supply. We expect $\lambda$ to be negative if firm clusters that are exposed to trading banks cannot replace the lost loan supply previously offered by trading banks with loans from non-trading banks.

Since we aggregate at the borrower level for the analysis in Equation (4), there are multiple ways to measure exposure to banks' securities trading. $\overline{\text { Exposure }}_{j t}$ is a proxy for exposure of a borrower to the securities trading of its lender banks and may be any of the following variables:

$$
\begin{aligned}
\overline{\text { Trading Exposure }}_{j t} & =\sum_{i} \omega_{j i t} \times \text { Trading Memberships } \\
\overline{\text { Trading Securities Exposure }}_{j t} & =\sum_{i} \omega_{j i t} \times \text { Securities Trading }_{i, t-1} \\
\overline{\text { Trading Exposure Stress }}_{j t} & =\sum_{i} \omega_{j i t} \times{\text { Trading Memberships } \times F S I_{i t}} \\
\overline{\text { Trading Securities Exposure Stress }}_{j t} & =\sum_{i} \omega_{j i t} \times \text { Securities Trading }_{i, t-1} \times F S I_{i t}
\end{aligned}
$$

where $\omega_{j i t}$ is equal to the share of loans granted by each bank $i$ to borrower $j$ in year $t$ and Trading Memberships and Securities Trading ${ }_{i, t-1}$ are defined as in the previous sections. $F S I_{i t}$ is a Financial Stress Index, measuring the level of stress in the financial market of bank $i$ 's country of incorporation. For example, $\overline{\text { Trading Exposure }}_{j t}$ is simply the share of loans granted to a borrower by banks with more extensive securities trading, and Trading Securities Exposure ${ }_{j t}$ represents the indirect exposure of borrowers to trading securities held by their lending banks. Moreover, by using $\overline{\text { Trading Exposure Stress }}_{j t}$ and $\overline{\text { Trading Securities Exposure Stress }}_{j t}$, we can capture the indirect exposure to the interaction between trading and financial market stress. We report summary statistics for all four exposure measures in Table 9. 


\section{Table 9: Characteristics of Firm Clusters}

Notes: In this table, we report the summary statistics for the firm clusters in our sample. Data for all firms and foreign currency exchange rates are obtained from Standard \& Poor's Compustat database. All non-USD values are converted to USD before any computations. The exposure variables are defined in Equations (5) - (8).

\begin{tabular}{|c|c|c|c|c|c|c|c|}
\hline & Mean & St. Dev. & Min & $\operatorname{Pctl}(25)$ & Median & $\operatorname{Pctl}(75)$ & $\operatorname{Max}$ \\
\hline$\overline{\text { Trading Exposure }}$ & 0.490 & 0.279 & 0.000 & 0.334 & 0.516 & 0.675 & 1.000 \\
\hline$\overline{\text { Securities Trading Exposure }}$ & 0.147 & 0.070 & 0.001 & 0.105 & 0.151 & 0.194 & 0.416 \\
\hline$\overline{\text { Trading Exposure Stress }}$ & 0.110 & 0.228 & 0.000 & 0.000 & 0.000 & 0.062 & 1.000 \\
\hline Securities Trading Exposure Stress & 0.037 & 0.073 & 0.000 & 0.000 & 0.000 & 0.032 & 0.416 \\
\hline
\end{tabular}

We report correlation coefficients for the correlation between each of the indirect exposure variables and the estimated loan demand in Table 10. All of the correlation coefficients are negative and statistically significant but rather small in magnitude. Recall that $\hat{\gamma}$ is the estimated loan demand. Thus, the negative correlation between indirect exposure to banks' trading and loan demand suggests that there is an, albeit weak, tendency that of borrowers with high loan demand to borrow from banks with less extensive securities trading. This reaffirms the importance of including the fixed effects $\gamma$ in our regression specifications in the previous sections to avoid bias from self-selection (Jimenez et al., 2011). However, the low magnitude of the correlations suggest a rather weak effect that appears to weaken further during financial crisis. 
Table 10: Correlations between Indirect Borrower Exposure and Loan Demand

Notes: In this table, we report correlations between indirect borrower exposure and loan demand. The exposure variables are defined in Equations (5) - (8). $\hat{\gamma}$ is the estimated loan demand, obtained as the fixed effects coefficients from Equations (1) and (3). Significance levels: ${ }^{*} p<0.1$; ${ }^{* *} p<0.05 ;{ }^{* * *} p<0.01$.

\section{Indirect Exposure:}

\begin{tabular}{ccc} 
& Trading Exposure & Trading Securities Exposure \\
\hline$\hat{\gamma}$ & $-0.157^{* * *}$ & $-0.213^{* * *}$ \\
\hline
\end{tabular}

\section{Indirect Exposure with Financial Stress:}

$\overline{\text { Trading Exposure Stress }} \overline{\text { Trading Securities Exposure Stress }}$

\begin{tabular}{lll}
\hline$\hat{\gamma}$ & $-0.069^{* * *}$ & $-0.064^{* * *}$ \\
\hline \hline
\end{tabular}

Finally, we are interested in the impact of borrowers' indirect exposure to banks' securities trading on borrowers' real economic activity. Therefore, we follow the approach in Acharya et al. (2018) and regress capital expenditures, changes in cash holdings, and employment growth on our four exposure variables. Specifically, we estimate the following model:

$$
y_{j t}=\theta{\overline{\text { Exposure }_{j t}}}_{j}+\boldsymbol{\Psi} \mathbf{G}_{\mathbf{j t}-\mathbf{1}}+\alpha_{j}+\alpha_{\text {Country } \times \text { Industry } \times Y e a r}+\alpha_{\text {Foreign Loan } \times Y e a r}+u_{j t},
$$

where $y_{j t}=\left[\right.$ Capex/TA ${ }_{j t}$, Employment Growth $\left.{ }_{j t}\right] . \overline{\text { Exposure }}_{j t}$ is any of the variables defined in Equations (5) to (8). $\alpha_{j}, \alpha_{\text {Country } \times \text { Industry } \times \text { Year }}$, and $\alpha_{\text {Foreign Loan } \times \text { Year }}$ are fixed effects that are defined in the same way as in Equation (4). $G_{j t-1}$ are borrower-level control variables. In line with our hypothesis regarding real effects, we expect $\theta$ to be negative, indicating that firms with greater exposure to trading banks suffer from a more restrictive loan supply and thus exhibit lower capital expenditures, lower employment growth, and less cash available.

\subsection{Results}

We present the estimation results for Equation (4) in Table 11. Consistent with our results in the previous sections, the estimated coefficients associated with $\overline{\text { Trading Securities Exposure }}_{t}$ 
and $\overline{\text { Trading Exposure }}_{t}$ are negative and statistically significant. Both coefficients also indicate an economically significant effect size. A one-standard-deviation increase in indirect securities trading

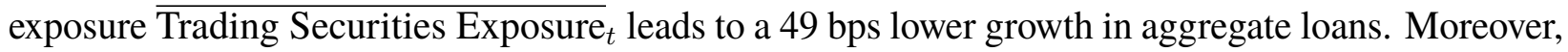
a one-standard-deviation increase in indirect trading exposure $\overline{\text { Trading Exposure }}_{t}$ leads to a $121 \mathrm{bps}$ lower growth in aggregate loans.

Compared to the results concerning the intensive margin, reported in Table 1, these results suggest that loan flows from exiting and new lending relationships pose an important margin of adjustment. Aggregate loan growth for non-financial borrowers is suppressed by lending banks' securities trading. Borrowers do not simply move to borrow from banks with less extensive securities trading but reduce their borrowing from banks overall. This leaves open the possibility that borrowers may replace bank loans with market-based forms of financing such as issuing bonds or equity. Unfortunately, we do not observe borrowers' bond or equity issuance or the resulting cash flows. However, one would expect that larger borrowers have easier access to market-based financing. In line with this notion, in all regression specifications in Table 11, the estimated coefficients associated with total assets are negative and statistically significant. This suggests that larger borrowers tend to borrow to a lesser degree from banks than do smaller borrowers.

The estimated coefficients associated with the indirect exposure measures that are interacted with the Financial Stress Index are negative but statistically not significant. Thus, there appears to be no crisis impact of banks' securities trading on the extensive margin of loan supply, implying that during periods of financial stress, lending relationships are unaffected. Taken together with the results regarding the intensive margin in the previous sections, this suggests that banks with more extensive securities trading reduce their loan supply by lowering the volume of loans, not by ending lending relationships.

Finally, we analyze whether the reduction in loan supply resulting from banks' securities trading affects borrowers' real economic activity. Specifically, we investigate the impact on capital expenditures and employment growth using the regression specification in Equation (9). We present 


\section{Table 11: Aggregate Loan Supply and Indirect Exposure to Securities Trading}

Notes: In this table, we present the estimation results for the effect of banks' securities trading on aggregate borrowing at the borrower level. The regression follows the specification in Equation (4). The sample consists of 1,716 individual firm clusters from 75 countries, examining the period from 2003 to 2016. The clusters are formed by matching firms according to their (1) country, (2) industry, and (3) and EBITDA interest coverage, following the approach in Acharya et al. (2018). Data for all firms and foreign currency exchange rates are obtained from Standard \& Poor's Compustat database. All non-USD values are converted to USD before any computations. Indirect exposure of firm clusters to their lending banks' securities trading is measured as defined in Equations (5) - (8). The results for the bank controls are reported in Table B.6 in Appendix B. All standard errors are clustered at the firm cluster level. Significance levels: ${ }^{*} p<0.1 ;{ }^{* *} p<0.05 ;{ }^{* * *} p<0.01$.

\begin{tabular}{|c|c|c|c|c|c|c|}
\hline & \multicolumn{6}{|c|}{ Dependent variable: $\Delta \log (\text { Aggregate Loan Volume })_{t}$} \\
\hline & $(1)$ & $(2)$ & (3) & (4) & $(5)$ & (6) \\
\hline$\overline{\text { Trading Securities Exposure }}_{t}$ & $\begin{array}{c}-6.985^{* *} \\
(3.190)\end{array}$ & & $\begin{array}{c}-8.157^{* *} \\
(3.397)\end{array}$ & & & \\
\hline$\overline{\text { Trading Exposure }}_{t}$ & & $\begin{array}{c}-4.329^{* * *} \\
(1.101)\end{array}$ & & $\begin{array}{c}-5.319^{* * *} \\
(1.174)\end{array}$ & & \\
\hline$\overline{\text { Trading Securities Stress }}_{t}$ & & & & & $\begin{array}{l}-1.409 \\
(1.742)\end{array}$ & \\
\hline$\overline{\text { Trading Exposure Stress }}_{t}$ & & & & & & $\begin{array}{l}-0.567 \\
(0.485)\end{array}$ \\
\hline Estimated Loan Demand & $\begin{array}{c}0.319^{* * *} \\
(0.026)\end{array}$ & $\begin{array}{c}0.308^{* * *} \\
(0.027)\end{array}$ & & & $\begin{array}{c}0.336^{* * *} \\
(0.030)\end{array}$ & $\begin{array}{c}0.335^{* * *} \\
(0.030)\end{array}$ \\
\hline Sales Growth $_{t-1}$ & $\begin{array}{l}0.356^{* *} \\
(0.146)\end{array}$ & $\begin{array}{l}0.350^{* *} \\
(0.145)\end{array}$ & $\begin{array}{c}0.407^{* * *} \\
(0.157)\end{array}$ & $\begin{array}{l}0.397^{* *} \\
(0.155)\end{array}$ & $\begin{array}{l}0.312^{* *} \\
(0.157)\end{array}$ & $\begin{array}{l}0.311^{* *} \\
(0.157)\end{array}$ \\
\hline $\log (\text { Total Assets })_{t-1}$ & $\begin{array}{c}-0.222^{* * *} \\
(0.084)\end{array}$ & $\begin{array}{c}-0.231^{* * *} \\
(0.083)\end{array}$ & $\begin{array}{l}-0.107 \\
(0.086)\end{array}$ & $\begin{array}{l}-0.122 \\
(0.084)\end{array}$ & $\begin{array}{c}-0.264^{* * *} \\
(0.089)\end{array}$ & $\begin{array}{c}-0.265^{* * *} \\
(0.089)\end{array}$ \\
\hline Intangible Assets/TA ${ }_{t-1}$ & $\begin{array}{l}-0.433 \\
(0.459)\end{array}$ & $\begin{array}{l}-0.351 \\
(0.451)\end{array}$ & $\begin{array}{l}-0.130 \\
(0.485)\end{array}$ & $\begin{array}{l}-0.041 \\
(0.468)\end{array}$ & $\begin{array}{l}-0.276 \\
(0.495)\end{array}$ & $\begin{array}{l}-0.283 \\
(0.496)\end{array}$ \\
\hline Leverage Ratio $_{t-1}$ & $\begin{array}{l}-0.633 \\
(0.650)\end{array}$ & $\begin{array}{l}-0.478 \\
(0.640)\end{array}$ & $\begin{array}{l}-0.742 \\
(0.687)\end{array}$ & $\begin{array}{l}-0.547 \\
(0.673)\end{array}$ & $\begin{array}{l}-0.540 \\
(0.697)\end{array}$ & $\begin{array}{l}-0.544 \\
(0.696)\end{array}$ \\
\hline $\mathrm{EBITDA} \mathrm{TA}_{t-1}$ & $\begin{array}{r}-0.080 \\
(5.472) \\
\end{array}$ & $\begin{array}{c}0.248 \\
(5.301) \\
\end{array}$ & $\begin{array}{l}-1.236 \\
(5.749) \\
\end{array}$ & $\begin{array}{r}-0.754 \\
(5.538) \\
\end{array}$ & $\begin{array}{c}0.484 \\
(5.567) \\
\end{array}$ & $\begin{array}{c}0.536 \\
(5.566) \\
\end{array}$ \\
\hline Observations & 13,659 & 13,659 & 13,659 & 13,659 & 11,521 & 11,521 \\
\hline Adjusted $\mathrm{R}^{2}$ & 0.614 & 0.619 & 0.578 & 0.585 & 0.617 & 0.618 \\
\hline Bank Controls & YES & YES & YES & YES & YES & YES \\
\hline Firm cluster FE & YES & YES & YES & YES & YES & YES \\
\hline Country-Industry-Year FE & YES & YES & YES & YES & YES & YES \\
\hline Foreign Loan-Year FE & YES & YES & YES & YES & YES & YES \\
\hline
\end{tabular}


the estimation results for the specification with capital expenditures as the dependent variable in Table 12 and those with employment growth as the dependent variable in Table 13. The estimated coefficients of the indirect exposure variables defined in Equations (5) to (8) are not statistically significant for any of the dependent variables. This is consistent with Chodorow-Reich (2014). Thus, despite facing lower bank loan supply, borrowers' real economic activity is not affected by their indirect exposure to banks' securities trading. This suggests that the borrowers in our sample can replace the reduced loan supply with other means of financing when necessary. 


\section{Table 12: Capital Expenditures and Indirect Exposure to Securities Trading}

Notes: In this table, we present the estimation results for the effect of banks' securities trading on aggregate borrowing at the borrower level. The regression follows the specification in Equation (4). The sample consists of 1,716 individual firm clusters from 75 countries, examining the period from 2003 to 2016. The clusters are formed by matching firms according to their (1) country, (2) industry, and (3) and EBITDA interest coverage, following the approach in Acharya et al. (2018). Data for all firms and foreign currency exchange rates are obtained from Standard \& Poor's Compustat database. All nonUSD values are converted to USD before any computations. Indirect exposure of firm clusters to their lending banks' securities trading is measured as defined in Equations (5) - (8). The estimated coefficients for bank controls are reported in the appendix. All standard errors are clustered at the firm cluster level. Significance levels: ${ }^{*} p<0.1 ;{ }^{* *} p<0.05 ;{ }^{* * *} p<0.01$.

\begin{tabular}{|c|c|c|c|c|}
\hline & \multicolumn{4}{|c|}{ Dependent variable: Capex $/ T A_{t}$} \\
\hline & $(1)$ & $(2)$ & (3) & (4) \\
\hline$\overline{\text { Trading Securities Exposure }}_{t}$ & $\begin{array}{c}0.018 \\
(0.037)\end{array}$ & & & \\
\hline$\overline{\text { Trading Exposure }}_{t}$ & & $\begin{array}{l}-0.011 \\
(0.010)\end{array}$ & & \\
\hline$\overline{\text { Trading Securities Stress }}_{t}$ & & & $\begin{array}{c}0.016 \\
(0.029)\end{array}$ & \\
\hline$\overline{\text { Trading Exposure Stress }}_{t}$ & & & & $\begin{array}{l}0.0001 \\
(0.008)\end{array}$ \\
\hline Sales Growth th-1 & $\begin{array}{c}0.005 \\
(0.003)\end{array}$ & $\begin{array}{c}0.005 \\
(0.003)\end{array}$ & $\begin{array}{c}0.006^{*} \\
(0.004)\end{array}$ & $\begin{array}{c}0.006^{*} \\
(0.004)\end{array}$ \\
\hline $\log (\text { Total Assets })_{t-1}$ & $\begin{array}{l}0.0004 \\
(0.002)\end{array}$ & $\begin{array}{l}0.0004 \\
(0.002)\end{array}$ & $\begin{array}{l}-0.001 \\
(0.002)\end{array}$ & $\begin{array}{l}-0.001 \\
(0.002)\end{array}$ \\
\hline Intangible Assets/TA ${ }_{t-1}$ & $\begin{array}{c}-0.039^{* * *} \\
(0.011)\end{array}$ & $\begin{array}{c}-0.039^{* * *} \\
(0.011)\end{array}$ & $\begin{array}{c}-0.039^{* * *} \\
(0.012)\end{array}$ & $\begin{array}{c}-0.039^{* * *} \\
(0.012)\end{array}$ \\
\hline Leverage Ratio ${ }_{t-1}$ & $\begin{array}{l}-0.013 \\
(0.009)\end{array}$ & $\begin{array}{l}-0.013 \\
(0.009)\end{array}$ & $\begin{array}{c}-0.017^{*} \\
(0.010)\end{array}$ & $\begin{array}{c}-0.017^{*} \\
(0.010)\end{array}$ \\
\hline $\mathrm{EBITDA} \mathrm{TA}_{t-1}$ & $\begin{array}{c}0.374^{* * *} \\
(0.137)\end{array}$ & $\begin{array}{c}0.378^{* * *} \\
(0.138)\end{array}$ & $\begin{array}{l}0.339^{* *} \\
(0.145)\end{array}$ & $\begin{array}{l}0.338^{* *} \\
(0.145)\end{array}$ \\
\hline Firm cluster FE & YES & YES & YES & YES \\
\hline Country-Industry-Year FE & YES & YES & YES & YES \\
\hline Foreign Loan-Year FE & YES & YES & YES & YES \\
\hline Observations & 13,659 & 13,659 & 11,521 & 11,521 \\
\hline Adjusted $\mathrm{R}^{2}$ & 0.755 & 0.755 & 0.738 & 0.738 \\
\hline
\end{tabular}


Table 13: Employment Growth and Indirect Exposure to Securities Trading

Notes: In this table, we present the estimation results for the effect of banks' securities trading on aggregate borrowing at the borrower level. The regression follows the specification in Equation (4). The sample consists of 1,716 individual firm clusters from 75 countries, examining the period from 2003 to 2016. The clusters are formed by matching firms according to their (1) country, (2) industry, and (3) and EBITDA interest coverage, following the approach in Acharya et al. (2018). Data for all firms and foreign currency exchange rates are obtained from Standard \& Poor's Compustat database. All non-USD values are converted to USD before any computations. Indirect exposure of firm clusters to their lending banks' securities trading is measured as defined in Equations (5) - (8). The estimated coefficients for bank controls are reported in the appendix. All standard errors are clustered at the firm cluster level. Significance levels: ${ }^{*} p<0.1 ;{ }^{* *} p<0.05 ;{ }^{* * *} p<0.01$.

\begin{tabular}{|c|c|c|c|c|}
\hline & \multicolumn{4}{|c|}{ Dependent variable: Employment Growth } \\
\hline & (1) & (2) & (3) & (4) \\
\hline$\overline{\text { Trading Securities Exposure }}_{t}$ & $\begin{array}{l}-0.021 \\
(0.218)\end{array}$ & & & \\
\hline$\overline{\text { Trading Exposure }}_{t}$ & & $\begin{array}{l}-0.106 \\
(0.072)\end{array}$ & & \\
\hline$\overline{\text { Trading Securities Stress }}_{t}$ & & & $\begin{array}{c}0.055 \\
(0.148)\end{array}$ & \\
\hline$\overline{\text { Trading Exposure Stress }}_{t}$ & & & & $\begin{array}{c}0.023 \\
(0.043)\end{array}$ \\
\hline Sales Growth t-1 $_{t}$ & $\begin{array}{c}0.459^{* * *} \\
(0.026)\end{array}$ & $\begin{array}{c}0.459^{* * *} \\
(0.026)\end{array}$ & $\begin{array}{c}0.479^{* * *} \\
(0.028)\end{array}$ & $\begin{array}{r}0.479^{* * * *} \\
(0.028)\end{array}$ \\
\hline $\log (\text { Total Assets })_{t-1}$ & $\begin{array}{c}0.026^{* * *} \\
(0.008)\end{array}$ & $\begin{array}{c}0.026^{* * *} \\
(0.008)\end{array}$ & $\begin{array}{c}0.024^{* * *} \\
(0.008)\end{array}$ & $\begin{array}{l}0.024^{* * *} \\
(0.008)\end{array}$ \\
\hline Intangible Assets/TA ${ }_{t-1}$ & $\begin{array}{l}0.090^{* *} \\
(0.043)\end{array}$ & $\begin{array}{l}0.091^{* *} \\
(0.043)\end{array}$ & $\begin{array}{c}0.066 \\
(0.046)\end{array}$ & $\begin{array}{c}0.066 \\
(0.046)\end{array}$ \\
\hline Leverage Ratio $_{t-1}$ & $\begin{array}{l}-0.035 \\
(0.030)\end{array}$ & $\begin{array}{c}-0.033 \\
(0.030)\end{array}$ & $\begin{array}{c}-0.016 \\
(0.031)\end{array}$ & $\begin{array}{l}-0.016 \\
(0.031)\end{array}$ \\
\hline $\mathrm{EBITDA} \mathrm{TA}_{t-1}$ & $\begin{array}{c}0.150 \\
(0.660)\end{array}$ & $\begin{array}{c}0.177 \\
(0.659)\end{array}$ & $\begin{array}{c}0.260 \\
(0.688)\end{array}$ & $\begin{array}{c}0.256 \\
(0.688)\end{array}$ \\
\hline Firm cluster FE & YES & YES & YES & YES \\
\hline Country-Industry-Year FE & YES & YES & YES & YES \\
\hline Foreign Loan-Year FE & YES & YES & YES & YES \\
\hline Observations & 13,659 & 13,659 & 11,521 & 11,521 \\
\hline Adjusted $\mathrm{R}^{2}$ & 0.313 & 0.314 & 0.323 & 0.323 \\
\hline
\end{tabular}




\section{Conclusion}

In this paper, we analyze the effects of banks' securities trading on their lending over the business cycle and during the financial crisis by analyzing a sample of banks and borrowers from 2003 to 2016, a period that spans both episodes in loan markets and financial market expansion and contraction. Most studies investigating bank lending focus on banking in individual countries or narrow geographical regions. However, large banks tend to operate globally across all of their business lines, including lending and securities trading. Therefore, in this paper, we analyze a global sample that includes 132 major banks from 21 countries and 7,763 borrowers from 76 countries spanning North America, Europe, and Asia. At the intensive margin, our empirical specification allows us to compare the loan flows to the same borrower from banks with more and less securities trading but otherwise similar characteristics. We show that banks with more extensive securities trading exhibit an approximately $20 \%$ lower annual loan growth than banks with less extensive securities trading. At the extensive margin, we show that the reduction in loan supply due to more extensive securities trading also extends to loan flows from new and exiting lending relationships. Exploiting our global sample, we find that banks with greater securities trading reduce loan supply to a greater extent in their domestic market than in foreign markets, despite an overall decline in foreign lending. Moreover, we find that our results are primarily driven by banks that are located in countries with deep financial markets.

Focusing on the additional impact of the financial crisis, the gap in loan supply between banks with more extensive securities trading and those with less extensive securities trading increases even further to approximately $31 \%$ lower loan growth during periods of financial crisis when stress in financial markets is high. As for the overall effect, this additional crisis impact is driven by banks located in deeper financial markets. Finally, although there is a significant reduction in loan supply, we do not find a significant impact on real economic activity, such as investments in capital and employment growth, on borrower side. This suggests that borrowers that cannot borrow from banks due to the reduced loan supply can replace bank loans with other forms of financing, such as 
retaining earnings or issuing debt securities or equities. Thus, although policy makers are concerned that banks allocate resources to securities trading activities at the expense of lending to non-financial firms, such behavior has no impact on real economic activity. However, if central banks, through there monetary policy, or other government institutions provide cheap funding to banks that are significantly engaged in securities trading, it is likely that those funds flow into securities trading rather than lending. This effect is likely to be stronger for banks located in countries with deeper financial markets. Moreover, banks with extensive trading operations that need to allocate capital to either trading or lending are more likely to cut lending in domestic than in foreign lending markets in the absence of financial crisis. Therefore, monetary policy that is aimed at increasing bank lending to non-financial firms after a crisis would likely be more effective if targeted explicitly at lending to the real economy. 


\section{References}

Abbassi, P., Iyer, R., Peydro, J.L., Tous, F.R., 2016. Securities trading by banks and credit supply: Micro-evidence from the crisis. Journal of Financial Economics 121, 569-594.

Acharya, V.V., Almeida, H., Ippolito, F., Perez, A., 2014a. A new perspective on bank-dependency: The liquidity insurance channel. ECB Working Paper .

Acharya, V.V., Almeida, H., Ippolito, F., Perez, A., 2014b. Credit lines as monitored liquidity insurance: Theory and evidence. Journal of Financial Economics 112, 287-319.

Acharya, V.V., Eisert, T., Eufinger, C., Hirsch, C., 2018. Real Effects of the Sovereign Debt Crisis in Europe: Evidence from Syndicated Loans. Review of Financial Studies 31, 2855-2896.

Adrian, T., Shin, H.S., 2013. Procyclical Leverage and Value-at-Risk. Review of Financial Studies 27, 373-403.

Argote, L., Miron-Spektor, E., 2011. Organizational Learning: from experience to knowledge. Organization Science 22, 1123-1137.

Arping, S., 2013. Propreity Trading and the Real Economy. Tinbergen Institute Discussion Paper .

Beck, T., Demirgüç-Kunt, A., Levine, R., 2010. Financial institutions and markets across countries and over time: The updated financial development and structure database. World Bank Economic Review 24, 77-92.

Blanchard, O.J., Das, M., Faruqee, H., 2010. The Initial Impact of the Crisis on Emerging Market Countries. Brookings Papers on Economic Activity, 263-307.

Blyth, C.R., 1972. On Simpson's Paradox and the Sure-Thing Principle. Journal of the American Statistical Association 67, 364-366.

Bocola, L., 2016. The pass-through of sovereign risk. Journal of Political Economy 124, 879-926.

Boot, A.W.A., Ratnovski, L., 2016. Banking and Trading. Review of Finance , 2219-2246.

Brunnermeier, M.K., Dong, G.N., Palia, D., 2012. Banks Non-Interest Income and Systemic Risk. AFA 2012 Chicago Meetings Paper .

Chodorow-Reich, G., 2014. The Employment Effects of Credit Market Disruptions: Firm-Level Evidence From The 2008-9 Financial Crisis. Quarterly Journal of Economics 129, 1-59.

Cingano, F., Manaresi, F., Sette, E., 2016. Does Credit Crunch Investment Down? New Evidence on the Real Effects of the Bank-Lending Channel. Review of Financial Studies 29, 2737-2773.

De Haas, R., Van Horen, N., 2012. Running for the Exit? International Bank Lending During a Financial Crisis. Review of Financial Studies 26, 244-285. 
De Jonghe, O., 2010. Back to the basics in banking? A micro-analysis of banking system stability. Journal of Financial Intermediation 19, 387-417.

De Young, R., Torna, G., 2013. Nontraditional banking activities and bank failures during the financial crisis. Journal of Financial Intermediation 22, 397-421.

Demirgüç-Kunt, A., Huizinga, H., 2010. Bank activity and funding strategies: The impact on risk and returns. Journal of Financial Economics 98, 626-650.

DeYoung, R., Rice, T., 2004. Noninterest income and financial performance at US commercial banks. Financial Review 39, 101-127.

Diamond, D.W., 1991. Monitoring and Reputation: The Choice between Bank Loans and Directly Placed Debt. Journal of Political Economy 99, 689-721.

Diamond, D.W., Rajan, R.G., 2011. Fear of fire sales, illiquidity seeking, and credit freezes. The Quarterly Journal of Economcis 126, 557-591.

Dreher, A., 2006. Does globalization affect growth? Evidence from a new index of globalization. Applied Economics 38, 1091-1110.

Edwards, F.R., Mishkin, F.S., 1995. The decline of traditional banking: Implications for financial stability and regulatory policy. FRBNY Economic Policy Review July, 27-47.

Erel, I., Julio, B., Kim, W., Weisbach, M.S., 2011. Macroeconomic Conditions and Capital Raising. Review of Financial Studies 25, 689-721.

Fahlenbrach, R., Prilmeier, R., Stiltz, R., 2012. This time is the same: Using bank performance in 1998 to explain bank performance during the recent financial crisis. Journal of Finance 67, 2139-2185.

Gambacorta, L., van Rixtel, A., 2013. Structural bank regulation initiatives: approaches and implications. BIS Working Papers No. 412 .

Goldstein, M., Xie, D., 2009. The Impact of the Financial Crisis on Emerging Asia. Peterson Institute for International Economics Working Paper Series WP 09-11.

Gygli, S., Haelg, F., Sturm, J.E., 2018. The KOF Globalisation Index - Revisited. KOF Working Papers No. 439 .

Ivashina, V., 2005. Structure and Pricing of Syndicated Loans, in: The New York City Area Conference on Financial Intermediation jointly sponsored by the Federal Reserve Bank of New York and the Salomon Center. New York, N.Y.

Ivashina, V., Scharfstein, D., 2010. Bank lending during the financial crisis of 2008. Journal of Financial Economics 97, 319-338. 
Iyer, R., Peydro, J.L., da Rocha-Lopes, Schoar, A., 2014. Interbank Liquidity Crunch and the Firm Credit Crunch: Evidence from the 2007-2009 Crisis. Review of Financial Studies 27, 347-372.

Jarmin, R.S., 1994. Learning by Doing and Competition in the Early Rayon Industry. The RAND Journal of Economics 25, 441-454.

Jimenez, G., Mian, A., Peydro, J.L., Saurina, J., 2011. Local Versus Aggregate Lending Channels: The Effects of Securitization on Corporate Credit Supply. Banco de Espana Working Paper No. 1124 .

Jimenez, G., Ongena, S., Peydro, J.L., Saurina, J., 2012. Credit Supply and Monetary Policy: Identifying the Bank Balance-Sheet Channel with Loan Applications. American Economic Review 102, 2301-2326.

Jimenez, G., Ongena, S., Peydro, J.L., Saurina, J., 2014. Hazardous Times for Monetary Policy: What Do Twenty-Three Million Bank Loans Say About the Effects of Monetary Policy on Credit Risk-Taking? Econometrica 82, 463-505.

Keat, H.S., 2009. The Global Financial Crisis: Impact on Asia and Poicy Challenges Ahead. Federal Reserve Bank of San Francisco Proceedings , 267-276.

Khwaja, A.I., Mian, A., 2008. Tracing the Impact of Bank Liquidity Shocks: Evidence from an Emerging Market. American Economic Review 98, 1413-1442.

Krahnen, J.P., Noth, F., Schüwer, U., 2017. Structural Reforms in Banking: The Role of Trading. Journal of Financial Regulation 3, 66-88.

Lehmann, M., 2016. Volcker rule, ring-fencing or separation of bank activities - Comparison of structural reform acts around the world. Journal of Banking Regulation 17, 176-187.

Liu, X., Pogach, J., 2017. The effect of foreign lending on domestic loans: An analysis of US global banks. Economics Letters 156, 151-154.

Marchetti, J., 2016. The International Banking Landscape: Developments, Drivers, and Potential Implications, in: Demirgüc-Kunt, A., Evanoff, D.D., Kaufman, G.G. (Eds.), The Future of Large, Internationally Active Banks. World Scientific Studies in International Economics 55. chapter 7, pp. 97-111.

Monin, P., 2017. The OFR Financial Stress Index. Office of Financial Research Working Paper 17-04.

Paravisini, D., Rappoport, V., Schnabl, P., 2017. Specialization in Bank Lending: Evidence from Exporting Firms. NBER Working Paper No 21800 .

Bonaccorsi di Patti, E., Sette, E., 2012. Bank balance sheets and the transmission of financial shocks to borrowers: evidence from the 2007-2008 crisis. Temi di discussione - Bank of Italy Working papers Number 848 . 
Repullo, R., 2018. Comments on How do bank-specific characteristics affect lending?, in: BIS Conference on Changes in bank's business models. Mexico City.

Schwert, M., 2018. Bank Capital and Lending Relationships. Journal of Finance 73, 787-830.

Shleifer, A., Vishny, 2010. Unstable banking. Journal of Financial Economics 97, 306-318.

Simpson, E.H., 1951. The Interpretation of Interaction in Contingency Tables. Journal of the Royal Statistical Society Series B, 238-241.

Stein, J.C., 2013. The Fire-Sales Problem and Securities Financing Transactions, in: Speech by Governor Jeremy C. Stein at the Federal Reserve Bank of New York Workshop on Fire Sales as a Driver of Systemic Risk in Triparty Repo and other Secured Funding Markets. New York, N.Y.

Sufi, A., 2007. Information asymetrie and financing arragements: Evidence from syndicated loans. Journal of Finance 62, 629-668.

Svirydzenka, K., 2016. Introducing a New Broad-based Index of Financial Development. IMF Working Paper .

Thompson, P., 2010. Learning by Doing, in: Hall, B.H., Rosenberg, N. (Eds.), Handbook of The Economics of Innovation. Elsevier. volume 1. chapter 10, pp. 429-476.

Veredas, D., Petkovic, A., 2010. Aggregation in linear models for panel data. Journal of the Japan Statistical Society 40, 63-95. 


\section{Appendix A. Summary Statistics}

\section{Table A.1: Bank Characteristics}

Notes: In this table, we present the summary statistics of the banks' characteristics for our 1,603 bank-year observations. The sample consists of 132 individual banks from 21 countries, examining the period from 2003 to 2016. Annual data for all banks are obtained from Standard \& Poor's Compustat database. All the characteristics are converted from local currency to USD using the unweighted average of the daily exchange rates in the relevant year. Daily foreign currency exchange rates are obtained from Compustat. Total Assets is the book value of total assets. Trading Securities is the USD volume of all trading and dealing accounts divided by total assets. Total Loans and Total Deposits are the book values of all loans granted to non-bank clients divided by total assets and all deposits received from non-bank clients divided by total assets, respectively. Accordingly, the Loans-to-Deposits Ratio is defined as the ratio of Total Loans to Total Deposits. The Capital Ratio is the ratio of the book value of the stockholders' equity to the book value of total assets. The Liquidity Ratio is computed as cash/total assets. \# Trading Memberships counts the number of trading memberships in the ten largest security exchanges worldwide and is measured by market volume. Trading Memberships is an indicator variable that is equal to one if a bank has at least one membership and zero otherwise. \# Trading Memberships $>2$ is an indicator variable that is equal to one if a bank has more than two trading memberships.

\begin{tabular}{|c|c|c|c|c|c|c|c|}
\hline Statistic & Mean & St. Dev. & Min & $\operatorname{Pctl}(25)$ & Median & $\operatorname{Pctl}(75)$ & Max \\
\hline $\log$ (Total Assets) & 12.491 & 1.286 & 10.632 & 11.306 & 12.435 & 13.600 & 14.898 \\
\hline Trading Securities & 0.087 & 0.116 & 0.000 & 0.003 & 0.033 & 0.130 & 0.677 \\
\hline ROA (in \%) & 0.582 & 0.543 & -1.146 & 0.275 & 0.564 & 0.947 & 1.760 \\
\hline Capital Ratio & 0.066 & 0.028 & 0.018 & 0.045 & 0.061 & 0.083 & 0.133 \\
\hline Liquidity Ratio & 0.038 & 0.033 & 0.005 & 0.014 & 0.027 & 0.052 & 0.125 \\
\hline Total Loans & 0.498 & 0.186 & 0.000 & 0.402 & 0.535 & 0.643 & 0.719 \\
\hline Total Deposits & 0.575 & 0.240 & 0.000 & 0.419 & 0.616 & 0.767 & 0.882 \\
\hline Loans-to-Deposits & 0.892 & 0.414 & 0.000 & 0.687 & 0.803 & 1.074 & 1.949 \\
\hline \# Trading Memberships & 2.025 & 2.865 & 0 & 0 & 1 & 2.8 & 10 \\
\hline Trading Memberships & 0.628 & \multicolumn{6}{|c|}{-} \\
\hline \# Trading Memberships $>2$ & 0.250 & \multicolumn{6}{|c|}{-} \\
\hline
\end{tabular}




\section{Table A.2: Banks by Region/Country}

Notes: In this table, we present the number of banks per country/region and the corresponding mean values within a relevant country/region. For the larger regions (the US, other advanced economies, and emerging economies), we also report the standard deviation within regions in parentheses. log(Total Assets) is the logarithm of the book value of total assets. \# Trading Memberships counts the number of trading memberships in the ten largest security exchanges worldwide measured by market volume. $\Delta \log$ (Loan Volume) is the year-on-year difference in the logarithm of loan volume.

\begin{tabular}{lcccc}
\hline Country/Region & \# of Banks & $\log ($ Total Assets) & \# Trading Memberships & $\Delta \log ($ Loan Volume $)$ \\
\hline US & 41 & 13.071 & 3.789 & 1.803 \\
& & $(1.273)$ & $(4.564)$ & $(2.476)$ \\
Other Advanced & 71 & 13.572 & 4.004 & 1.296 \\
& & $(1.064)$ & $(3.039)$ & $(2.150)$ \\
Canada & 5 & 13.045 & 3.554 & 1.678 \\
European Union & 32 & 13.868 & 4.833 & 1.249 \\
Switzerland & 3 & 13.925 & 9.939 & 1.504 \\
Japan & 23 & 13.108 & 1.308 & 1.263 \\
Australia & 7 & 12.777 & 0.993 & 0.876 \\
& & & & 0.568 \\
Emerging & 24 & 12.857 & 1.073 & $(1.421)$ \\
& & $(1.288)$ & $(1.117)$ & 0.627 \\
China & 13 & 13.992 & & 0.445 \\
Hong Kong & 2 & 11.397 & 1.885 & 0.591 \\
Singapore & 2 & 12.084 & 1.000 & 0.311 \\
South Korea & 4 & 12.294 & 0.000 & 0.426 \\
Taiwan & 2 & 11.352 & 0.000 & 0.586 \\
Brazil & 1 & 12.554 & 0.192 & \\
\hline
\end{tabular}




\section{Table A.3: Financial Market Depth}

Notes: In this table, we present the summary statistics for the financial depth index for each bank country except Taiwan. Data on the index are available through the website of the IMF. The financial market depth index is a sub-index of the IMF's financial development index. Details on the scope and computation of the financial development index and its sub-indices can be found in Svirydzenka (2016). Financial market depth comprises data on a country's stock market capitalization divided by GDP, stocks traded divided by GDP, international debt securities of the government divided by GDP, and total debt securities of financial and non-financial firms divided by GDP.

\begin{tabular}{lccccccc}
\hline \hline Country & Mean & St. Dev. & Min & Pctl(25) & Median & Pctl(75) & Max \\
\hline Australia & 0.916 & 0.046 & 0.817 & 0.898 & 0.913 & 0.951 & 0.984 \\
Austria & 0.487 & 0.064 & 0.376 & 0.455 & 0.482 & 0.500 & 0.637 \\
Brazil & 0.371 & 0.084 & 0.261 & 0.317 & 0.347 & 0.397 & 0.550 \\
Canada & 0.925 & 0.087 & 0.777 & 0.841 & 0.980 & 0.999 & 1.000 \\
Switzerland & 0.946 & 0.083 & 0.779 & 0.985 & 0.987 & 0.987 & 0.987 \\
China & 0.495 & 0.171 & 0.200 & 0.392 & 0.559 & 0.616 & 0.681 \\
Germany & 0.690 & 0.060 & 0.629 & 0.643 & 0.675 & 0.716 & 0.822 \\
Denmark & 0.618 & 0.116 & 0.364 & 0.562 & 0.661 & 0.678 & 0.782 \\
Spain & 0.897 & 0.058 & 0.806 & 0.839 & 0.909 & 0.942 & 0.978 \\
Finland & 0.747 & 0.086 & 0.543 & 0.728 & 0.764 & 0.812 & 0.843 \\
France & 0.856 & 0.060 & 0.792 & 0.824 & 0.851 & 0.856 & 0.988 \\
UK & 0.979 & 0.026 & 0.888 & 0.985 & 0.986 & 0.988 & 0.989 \\
Hongkong & 0.828 & 0.007 & 0.814 & 0.821 & 0.830 & 0.833 & 0.836 \\
Ireland & 0.583 & 0.048 & 0.506 & 0.550 & 0.581 & 0.616 & 0.686 \\
Italy & 0.637 & 0.061 & 0.564 & 0.589 & 0.621 & 0.695 & 0.738 \\
Japan & 0.733 & 0.097 & 0.536 & 0.687 & 0.729 & 0.799 & 0.894 \\
Korea & 0.750 & 0.106 & 0.591 & 0.661 & 0.792 & 0.834 & 0.879 \\
Netherlands & 0.923 & 0.043 & 0.832 & 0.897 & 0.931 & 0.941 & 0.989 \\
Singapore & 0.894 & 0.024 & 0.861 & 0.878 & 0.885 & 0.912 & 0.934 \\
USA & 0.983 & 0.017 & 0.925 & 0.987 & 0.987 & 0.987 & 0.987 \\
\hline \hline
\end{tabular}




\section{Table A.4: Characteristics of Firm Clusters}

Notes: In this table, we present the summary statistics for the firm clusters in our sample. The sample consists of 1,725 individual firm clusters from 76 countries, examining the period from 2003 to 2016. The firm clusters are based on 7,763 individual firms, such that the average cluster consists of 4.5 firms. The clusters are formed by matching firms according to their (1) country, (2) industry, and (3) and EBITDA interest coverage, following the approach in Acharya et al. (2018). Data for all firms and foreign currency exchange rates are obtained from Standard \& Poor's Compustat database. All non-USD values are converted to USD before any computations. $\log ($ Assets) is the logarithm of the book value of total assets. Capex refers to the capital expenditure. Employment Growth is the year-to-year change in the logarithm of the number of employees. Cash includes cash and cash equivalents. Net Debt is the sum of short-term and long-term debt minus cash and cash equivalents. Short-term Debt is all debt with a remaining time to maturity of up to one year, and Long-term Debt is all debt with a remaining time to maturity of more than one year.

\begin{tabular}{lccccccc}
\hline \hline Statistic & Mean & St. Dev. & Min & Pctl(25) & Median & Pctl(75) & Max \\
\hline Capex/Assets & 0.049 & 0.035 & 0.006 & 0.023 & 0.040 & 0.067 & 0.129 \\
Employment Growth & 0.028 & 0.155 & -0.297 & -0.041 & 0.015 & 0.087 & 0.387 \\
$\log ($ Assets) & 8.726 & 1.672 & 6.686 & 7.230 & 8.524 & 9.899 & 12.723 \\
Cash/Assets & 0.008 & 0.036 & -0.053 & -0.013 & 0.004 & 0.027 & 0.084 \\
Net Debt/Assets & 0.397 & 0.176 & 0.043 & 0.285 & 0.410 & 0.528 & 0.682 \\
Intangible/Assets & 0.161 & 0.165 & 0.005 & 0.023 & 0.097 & 0.261 & 0.551 \\
Ebitda/Assets & 0.008 & 0.009 & 0.00004 & 0.001 & 0.004 & 0.012 & 0.027 \\
\hline
\end{tabular}




\section{Appendix B. Control Variables}

\section{Table B.1: Securities Trading and Bank Lending - Controls}

Notes: In this table, we present the results for the bank control variables associated with the regressions shown in Table

1. Standard errors are clustered at the bank-firm cluster level. Significance levels: ${ }^{*} p<0.1 ;{ }^{* *} p<0.05 ;{ }^{* * *} p<0.01$. Dependent variable: $\Delta \log (\text { Loan Volume })_{i j t}$

(1)

Sales Growth $_{j, t}$

Leverage $_{j, t}$

$\log (\text { Total Assets })_{j, t}$

Capex/TA $_{j, t}$

Net Debt/TA ${ }_{j, t}$

Employment Growth $_{j, t}$
(2)

(3)

(4)

(5)

$0.295^{* * *} \quad 0.294^{* * *}$

(0.038) (0.038)

$-1.020^{* * *}-1.009^{* * *}$

$(0.136) \quad(0.136)$

$0.374^{* * *} \quad 0.374^{* * *}$

(0.006) (0.006)

$0.071 \quad 0.069$

(0.246) (0.246)

$1.357^{* * *} \quad 1.351^{* * *}$

(0.118) (0.118)

$0.193^{* * *} \quad 0.193^{* * *}$

(0.029) (0.029)

\begin{tabular}{lcccccc}
\hline Firm Cluster-Year FE & NO & NO & YES & YES & NO & NO \\
Bank Country-Year FE & YES & YES & YES & YES & YES & YES \\
Firm Cluster Controls & NO & NO & NO & NO & YES & YES \\
Borrower Country-Year FE & NO & NO & NO & NO & YES & YES \\
Borrower SIC-Year FE & NO & NO & NO & NO & YES & YES \\
\hline Observations & 267,326 & 267,326 & 267,326 & 267,326 & 267,326 & 267,326 \\
Adjusted R & 0.075 & 0.076 & 0.375 & 0.376 & 0.215 & 0.216 \\
\hline
\end{tabular}


Table B.2: Is Foreign Lending Affected Differently than Domestic Lending by Securities Trading? - Controls

Notes: In this table, we present the results for the bank control variables associated with the regressions shown in Table 3. Standard errors are clustered at the bank-firm cluster level. Significance levels: ${ }^{*} p<0.1 ;{ }^{* *} p<0.05 ;{ }^{* * *} p<0.01$.

\begin{tabular}{lcccccc}
\hline \hline & \multicolumn{5}{c}{ Dependent Variable: $\Delta \log ($ Loan Volume $)$} \\
\cline { 2 - 7 } & $(1)$ & $(2)$ & $(3)$ & $(4)$ & $(5)$ & $(6)$ \\
\hline $\log {\text { (Total Assets })_{i, t-1}}$ & $0.647^{* * *}$ & $0.658^{* * *}$ & $0.551^{* * *}$ & $0.633^{* * *}$ & $0.648^{* * *}$ & $0.529^{* * *}$ \\
& $(0.011)$ & $(0.011)$ & $(0.012)$ & $(0.012)$ & $(0.012)$ & $(0.012)$ \\
Liquidity Ratio $_{i, t-1}$ & $3.176^{* * *}$ & $3.327^{* * *}$ & $1.943^{* * *}$ & $3.369^{* * *}$ & $3.584^{* * *}$ & $2.266^{* * *}$ \\
& $(0.312)$ & $(0.311)$ & $(0.318)$ & $(0.316)$ & $(0.315)$ & $(0.323)$ \\
ROA $_{i, t-1}$ & -0.386 & -0.778 & 3.360 & 3.079 & 2.529 & $5.764^{* * *}$ \\
& $(1.959)$ & $(1.951)$ & $(2.068)$ & $(1.946)$ & $(1.936)$ & $(2.055)$ \\
Capital Ratio $_{i, t-1}$ & $4.950^{* * *}$ & $4.992^{* * *}$ & $4.119^{* * *}$ & $5.610^{* * *}$ & $5.607^{* * *}$ & $4.352^{* * *}$ \\
& $(0.564)$ & $(0.564)$ & $(0.585)$ & $(0.574)$ & $(0.572)$ & $(0.601)$ \\
Loans-To-Deposits $_{i, t-1}$ & $0.101^{* * *}$ & $0.092^{* * *}$ & $0.116^{* * *}$ & $0.129^{* * *}$ & $0.120^{* * *}$ & $0.136^{* * *}$ \\
& $(0.029)$ & $(0.029)$ & $(0.029)$ & $(0.030)$ & $(0.030)$ & $(0.029)$ \\
\hline Observations & 267,326 & 267,326 & 266,257 & 267,326 & 267,326 & 266,257 \\
Adjusted R & 0.413 & 0.416 & 0.386 & 0.413 & 0.416 & 0.385 \\
\hline Bank Controls & YES & YES & YES & YES & YES & YES \\
Firm Cluster-Year FE & YES & YES & YES & YES & YES & YES \\
Bank Country-Year FE & YES & YES & YES & YES & YES & YES \\
\hline \hline
\end{tabular}


Table B.3: Is Foreign Lending Affected Differently than Domestic Lending by Securities Trading? - Crisis Impact

Notes: In this table, we present the results for the bank control variables associated with the regressions shown in Table 4. Standard errors are clustered at the bank-firm cluster level. Significance levels: ${ }^{*} p<0.1 ;{ }^{* *} p<0.05 ;{ }^{* * *} p<0.01$.

\begin{tabular}{|c|c|c|c|c|c|c|}
\hline & \multicolumn{6}{|c|}{ Dependent Variable: $\Delta \log ($ Loan Volume $)$} \\
\hline & (1) & (2) & (3) & (4) & $(5)$ & (6) \\
\hline Foreign Lending & $\begin{array}{c}-1.483^{* * *} \\
(0.034)\end{array}$ & & & $\begin{array}{c}-1.471^{* * *} \\
(0.034)\end{array}$ & & \\
\hline $\log ($ Distance $)$ & & $\begin{array}{c}-0.174^{* * *} \\
(0.004)\end{array}$ & & & $\begin{array}{c}-0.179^{* * *} \\
(0.004)\end{array}$ & \\
\hline Economic Distance & & & $\begin{array}{c}-0.062^{* * *} \\
(0.002)\end{array}$ & & & $\begin{array}{c}-0.058^{* * *} \\
(0.002)\end{array}$ \\
\hline Financial Crisis & $\begin{array}{c}0.134^{* * *} \\
(0.024)\end{array}$ & $\begin{array}{c}0.118^{* * *} \\
(0.024)\end{array}$ & $\begin{array}{c}0.152^{* * *} \\
(0.021)\end{array}$ & $\begin{array}{c}0.120^{* * *} \\
(0.025)\end{array}$ & $\begin{array}{c}0.091^{* * *} \\
(0.025)\end{array}$ & $\begin{array}{c}0.147^{* * *} \\
(0.022)\end{array}$ \\
\hline $\log (\text { Total Assets })_{i, t-1}$ & $\begin{array}{c}0.636^{* * *} \\
(0.011)\end{array}$ & $\begin{array}{c}0.645^{* * *} \\
(0.011)\end{array}$ & $\begin{array}{c}0.542^{* * *} \\
(0.011)\end{array}$ & $\begin{array}{c}0.623^{* * *} \\
(0.011)\end{array}$ & $\begin{array}{c}0.636^{* * *} \\
(0.011)\end{array}$ & $\begin{array}{c}0.522^{* * *} \\
(0.011)\end{array}$ \\
\hline Liquidity Ratio $_{i, t-1}$ & $\begin{array}{c}2.119^{* * *} \\
(0.214)\end{array}$ & $\begin{array}{c}2.216^{* * *} \\
(0.214)\end{array}$ & $\begin{array}{c}1.340^{* * *} \\
(0.218)\end{array}$ & $\begin{array}{c}2.035^{* * *} \\
(0.221)\end{array}$ & $\begin{array}{c}2.165^{* * *} \\
(0.220)\end{array}$ & $\begin{array}{c}1.513^{* * *} \\
(0.226)\end{array}$ \\
\hline $\mathrm{ROA}_{i, t-1}$ & $\begin{array}{c}6.016^{* * *} \\
(1.483)\end{array}$ & $\begin{array}{c}5.642^{* * *} \\
(1.480)\end{array}$ & $\begin{array}{c}8.200^{* * *} \\
(1.547)\end{array}$ & $\begin{array}{c}8.936^{* * *} \\
(1.471)\end{array}$ & $\begin{array}{c}8.301^{* * *} \\
(1.467)\end{array}$ & $\begin{array}{c}10.506^{* * *} \\
(1.533)\end{array}$ \\
\hline Capital Ratio $_{i, t-1}$ & $\begin{array}{c}5.396^{* * *} \\
(0.464)\end{array}$ & $\begin{array}{c}5.476^{* * *} \\
(0.464)\end{array}$ & $\begin{array}{c}4.392^{* * *} \\
(0.479)\end{array}$ & $\begin{array}{c}5.905^{* * *} \\
(0.473)\end{array}$ & $\begin{array}{c}5.968^{* * *} \\
(0.472)\end{array}$ & $\begin{array}{r}4.488^{* * *} \\
(0.492)\end{array}$ \\
\hline Loans-To-Deposits $_{i, t-1}$ & $\begin{array}{l}0.055^{* *} \\
(0.024)\end{array}$ & $\begin{array}{l}0.047^{* *} \\
(0.024)\end{array}$ & $\begin{array}{c}0.072^{* * *} \\
(0.023)\end{array}$ & $\begin{array}{c}0.068^{* * *} \\
(0.024)\end{array}$ & $\begin{array}{l}0.058^{* *} \\
(0.024)\end{array}$ & $\begin{array}{c}0.086^{* * *} \\
(0.024)\end{array}$ \\
\hline Foreign Lending*Financial Crisis & $\begin{array}{c}0.067^{* * *} \\
(0.025)\end{array}$ & & & $\begin{array}{l}0.063^{* *} \\
(0.028)\end{array}$ & & \\
\hline $\log (\text { Distance })^{*}$ Financial Crisis & & $\begin{array}{c}0.011^{* * *} \\
(0.003)\end{array}$ & & & $\begin{array}{c}0.012^{* * *} \\
(0.003)\end{array}$ & \\
\hline Economic Distance*Financial Crisis & & & $\begin{array}{c}0.006^{* * *} \\
(0.002) \\
\end{array}$ & & & $\begin{array}{c}0.006^{* * *} \\
(0.002) \\
\end{array}$ \\
\hline $\begin{array}{l}\text { Observations } \\
\text { Adjusted } \mathrm{R}^{2}\end{array}$ & $\begin{array}{c}264,716 \\
0.410\end{array}$ & $\begin{array}{c}264,716 \\
0.413\end{array}$ & $\begin{array}{c}263,691 \\
0.383\end{array}$ & $\begin{array}{c}264,716 \\
0.409\end{array}$ & $\begin{array}{c}264,716 \\
0.412\end{array}$ & $\begin{array}{c}263,691 \\
0.382\end{array}$ \\
\hline Bank Controls & YES & YES & YES & YES & YES & YES \\
\hline Firm Cluster-Year FE & YES & YES & YES & YES & YES & YES \\
\hline Bank Country FE & YES & YES & YES & YES & YES & YES \\
\hline
\end{tabular}




\section{Table B.4: Financial Market Depth - Controls}

Notes: In this table, we present the results for the bank control variables associated with the regressions shown in Table

6. Standard errors are clustered at the bank-firm cluster level. Significance levels: ${ }^{*} p<0.1 ;{ }^{* *} p<0.05 ;{ }^{* * *} p<0.01$.

\begin{tabular}{|c|c|c|c|c|}
\hline & \multicolumn{4}{|c|}{ Dependent variable: $\Delta \log (\text { Loan Volume })_{j, i, t}$} \\
\hline & (1) & $(2)$ & (3) & (4) \\
\hline $\log (\text { Total Assets })_{i, t-1}$ & $\begin{array}{c}0.476^{* * *} \\
(0.011)\end{array}$ & $\begin{array}{c}0.498^{* * *} \\
(0.011)\end{array}$ & $\begin{array}{c}0.479^{* * *} \\
(0.011)\end{array}$ & $\begin{array}{c}0.501^{\text {*** }} \\
(0.011)\end{array}$ \\
\hline Liquidity Ratio $_{i, t-1}$ & $\begin{array}{c}1.121^{\text {*** }} \\
(0.229)\end{array}$ & $\begin{array}{c}0.689^{* * *} \\
(0.216)\end{array}$ & $\begin{array}{c}1.104^{* * *} \\
(0.230)\end{array}$ & $\begin{array}{c}0.697^{* * *} \\
(0.217)\end{array}$ \\
\hline Capital Ratio $_{i, t-1}$ & $\begin{array}{c}3.503^{* * *} \\
(0.498)\end{array}$ & $\begin{array}{c}3.769^{* * *} \\
(0.482)\end{array}$ & $\begin{array}{c}3.340^{* * *} \\
(0.501)\end{array}$ & $\begin{array}{c}3.570^{\text {*** }} \\
(0.486)\end{array}$ \\
\hline Loans-To-Deposits $_{i, t-1}$ & $\begin{array}{c}0.111^{* * *} \\
(0.023)\end{array}$ & $\begin{array}{c}0.096^{* * *} \\
(0.023)\end{array}$ & $\begin{array}{c}0.105^{* * *} \\
(0.024)\end{array}$ & $\begin{array}{c}0.094^{* * *} \\
(0.023)\end{array}$ \\
\hline $\mathrm{ROA}_{i, t-1}$ & $\begin{array}{c}10.081^{* * *} \\
(1.571)\end{array}$ & $\begin{array}{c}9.680^{* * *} \\
(1.584)\end{array}$ & $\begin{array}{c}9.041^{* * *} \\
(1.581)\end{array}$ & $\begin{array}{c}8.689^{* * *} \\
(1.595)\end{array}$ \\
\hline Observations & 267,326 & 267,326 & 264,716 & 264,716 \\
\hline Adjusted $\mathrm{R}^{2}$ & 0.371 & 0.371 & 0.373 & 0.373 \\
\hline Bank Controls & YES & YES & YES & YES \\
\hline Firm Cluster-Year FE & YES & YES & YES & YES \\
\hline Bank Country FE & YES & YES & YES & YES \\
\hline
\end{tabular}


Table B.5: The Effect of Trading on Loan Pricing - Controls

Notes: In this table, we present the results for the bank control variables associated with the regressions shown in Table 8. Standard errors are clustered at the bank-firm cluster level. Significance levels: ${ }^{*} p<0.1 ;{ }^{* *} p<0.05 ;{ }^{* * *} p<0.01$.

\begin{tabular}{lcccccc}
\hline \hline & \multicolumn{5}{c}{ Dependent } & variable: $\Delta$ (All-in Spread Drawn $)_{i j t}$ \\
\cline { 2 - 7 } & $(1)$ & $(2)$ & $(3)$ & $(4)$ & $(5)$ & $(6)$ \\
\hline $\log (\text { Total Assets })_{i, t-1}$ & $-0.664^{* * *}$ & $-0.667^{* * *}$ & $-0.733^{* * *}$ & $-0.727^{* * *}$ & $-0.655^{* * *}$ & $-0.715^{* * *}$ \\
& $(0.090)$ & $(0.090)$ & $(0.090)$ & $(0.090)$ & $(0.091)$ & $(0.091)$ \\
Liquidity Ratio $_{i, t-1}$ & $-8.956^{* *}$ & $-8.968^{* *}$ & $-7.607^{*}$ & $-7.487^{*}$ & $-9.096^{* *}$ & $-7.140^{*}$ \\
& $(4.150)$ & $(4.150)$ & $(4.135)$ & $(4.140)$ & $(4.166)$ & $(4.133)$ \\
Capital Ratio $_{i, t-1}$ & $27.382^{* * *}$ & $27.656^{* * *}$ & $26.338^{* * *}$ & $26.046^{* * *}$ & $24.373^{* * *}$ & $22.831^{* * *}$ \\
& $(7.276)$ & $(7.298)$ & $(7.077)$ & $(7.098)$ & $(7.237)$ & $(7.019)$ \\
Loans-To-Deposits $_{i, t-1}$ & $-0.925^{* *}$ & $-0.904^{* *}$ & $-0.939^{* *}$ & $-0.947^{* *}$ & $-1.029^{* *}$ & $-0.980^{* *}$ \\
& $(0.427)$ & $(0.427)$ & $(0.412)$ & $(0.411)$ & $(0.425)$ & $(0.408)$ \\
ROA $_{i, t-1}$ & -54.386 & -54.282 & -53.682 & -54.427 & -52.481 & -48.915 \\
& $(42.376)$ & $(42.374)$ & $(40.872)$ & $(40.847)$ & $(41.911)$ & $(40.479)$ \\
\hline Bank Controls & YES & YES & YES & YES & YES & YES \\
Firm Cluster-Year FE & YES & YES & YES & YES & YES & YES \\
Bank Country FE & YES & YES & YES & YES & YES & YES \\
\hline Observations & 200,570 & 200,570 & 200,570 & 200,570 & 200,570 & 200,570 \\
Adjusted R & 0.265 & 0.265 & 0.265 & 0.265 & 0.265 & 0.265 \\
\hline \hline
\end{tabular}




\section{Table B.6: Aggregate Loan Supply and Indirect Exposure to Securities Trading - Controls}

Notes: In this table, we present the results for the bank control variables associated with the regressions shown in Table 11. Standard errors are clustered at the bank-firm cluster level. Significance levels: ${ }^{*} p<0.1 ;{ }^{* *} p<0.05 ;{ }^{* * *} p<0.01$.

\begin{tabular}{lcccccc}
\hline \hline & \multicolumn{5}{c}{ Dependent variable: $\Delta \log (\text { Aggregate Loan Volume })_{t}$} \\
\cline { 2 - 7 } & $(1)$ & $(2)$ & $(3)$ & $(4)$ & $(5)$ & $(6)$ \\
\hline$\overline{\text { Liquidity Ratio }}_{t-1}$ & 1.662 & 0.746 & 1.682 & 0.657 & 0.045 & 0.126 \\
& $(5.036)$ & $(5.095)$ & $(5.578)$ & $(5.606)$ & $(5.381)$ & $(5.382)$ \\
$\overline{\text { Capital Ratio }}_{t-1}$ & $47.098^{* * *}$ & $40.337^{* * *}$ & $69.137^{* * *}$ & $59.479^{* * *}$ & $49.155^{* * *}$ & $49.624^{* * *}$ \\
& $(12.138)$ & $(12.083)$ & $(12.937)$ & $(12.821)$ & $(13.222)$ & $(13.145)$ \\
$\overline{\mathrm{ROA}}_{t-1}$ & 46.703 & 36.372 & 50.613 & 37.035 & 39.279 & 39.871 \\
& $(35.282)$ & $(35.042)$ & $(37.262)$ & $(37.173)$ & $(37.914)$ & $(37.945)$ \\
$\overline{\text { Loans-To-Deposits }}_{t-1}$ & 0.366 & 0.384 & 0.149 & 0.185 & -0.082 & -0.082 \\
& $(0.558)$ & $(0.561)$ & $(0.587)$ & $(0.589)$ & $(0.637)$ & $(0.639)$ \\
& $0.869^{* *}$ & $0.901^{* *}$ & $1.147^{* * *}$ & $1.187^{* * *}$ & $0.762^{* *}$ & $0.781^{* *}$ \\
Total Assets $_{t-1}$ & $(0.364)$ & $(0.352)$ & $(0.391)$ & $(0.378)$ & $(0.385)$ & $(0.384)$ \\
& 13,659 & 13,659 & 13,659 & 13,659 & 11,521 & 11,521 \\
Observations $_{\text {Adjusted R }}^{2}$ & 0.614 & 0.619 & 0.578 & 0.585 & 0.617 & 0.618 \\
\hline Bank Controls & YES & YES & YES & YES & YES & YES \\
Firm cluster FE & YES & YES & YES & YES & YES & YES \\
Country-Industry-Year FE & YES & YES & YES & YES & YES & YES \\
Foreign Loan-Year FE & YES & YES & YES & YES & YES & YES \\
\hline \hline
\end{tabular}




\section{Appendix C. Estimating Fixed-Effects Models with Aggregated Observations}

We now discuss the implications of applying our model (1) and model (9) regressions to firm clusters rather than individual firms. This appendix relies heavily on Veredas and Petkovic (2010). Generally, we are interested in estimating a model of the following form:

$$
y_{z, t}=\gamma_{z}+\beta f_{z, t}+u_{z, t}
$$

where $z=1,2, \ldots, Z$ indexes individual firms. However, as in our specifications for model (1) and model (9), we must aggregate individual firms into groups $j=1,2, \ldots, J$ with $J<Z$. Thus, we define an aggregation scheme such that

$$
\tilde{y}_{j, t}=\sum_{z=1}^{Z} M_{z}^{j} y_{z, t}
$$

where $M_{z}^{j}=1$ or 0 , such that $\sum_{j=1}^{J} \sum_{z=1}^{Z} M_{z}^{j}=J$, i.e., we sum the individuals belonging to group $j$. We further require $\sum_{z=1}^{Z} M_{z}^{j} M_{z}^{j^{\prime}}=0 \forall a^{\prime} \neq a$, i.e., that individual firms can belong to only one group. Without loss of generality, we consider a simplified case with only a single independent variable and only individual fixed effects. We focus on a specification equivalent to our model (9). All results shown below can easy be applied to apply to our model (1) specification.

Applying this aggregation scheme to the regression equation, (C.1) yields

$$
\begin{aligned}
\sum_{z=1}^{Z} M_{z}^{j} y_{z, t} & =\sum_{z=1}^{Z} M_{z}^{j} \gamma_{z}+\sum_{z=1}^{Z} \beta M_{z}^{j} f_{z, t}+\sum_{z=1}^{Z} M_{z}^{j} u_{z, t} \\
\tilde{y}_{j, t} & =\gamma_{j}+\beta \tilde{f}_{j, t}+\tilde{u}_{j, t}
\end{aligned}
$$

Thus, the population slope parameter is not affected by the aggregation, as we assume slopes are constant for individual firms. The group fixed effects $\gamma_{j}$ are simply the sum of the individual fixed effects in each group. Note that in terms of our model ((1), we have $\tilde{x}_{i, t}=x_{i, t}$, since the control variables are bank-level rather than firm-level variables, and $\sum_{z=1}^{Z} M_{z}^{j}=1$. $^{15}$

To understand how aggregation affects parameter estimation and inference, we write the model in matrix notation.

$$
\begin{aligned}
\left\{\begin{array}{c}
\mathbf{y}_{\mathbf{1}} \\
\mathbf{y}_{\mathbf{2}} \\
\vdots \\
\mathbf{y}_{\mathbf{Z}}
\end{array}\right\} & =\left\{\begin{array}{c}
\gamma_{1} \mathbf{e}_{\mathbf{N}} \\
\gamma_{2} \mathbf{e}_{\mathbf{N}} \\
\vdots \\
\gamma_{Z} \mathbf{e}_{\mathbf{N}}
\end{array}\right\}+\left\{\begin{array}{c}
\mathbf{f}_{1} \\
\mathbf{f}_{2} \\
\vdots \\
\mathbf{f}_{\mathbf{Z}}
\end{array}\right\} \beta+\left\{\begin{array}{c}
\mathbf{u}_{1} \\
\mathbf{u}_{2} \\
\vdots \\
\mathbf{u}_{\mathbf{Z}}
\end{array}\right\} \\
\mathbf{Y} & =\mathbf{G}+\mathbf{F} \beta+\mathbf{U}
\end{aligned}
$$

where $\mathbf{y}_{\mathbf{z}}$ and $\mathbf{f}_{\mathbf{z}}$ are $(N \times 1)$ vectors containing the observations for individual firm $z . \gamma_{z}$ are

\footnotetext{
${ }^{15}$ Obviously, the same applies to the bank country-year fixed effect.
} 
individual firm fixed effects and $\mathbf{e}_{\mathbf{N}}$ are $(N \times 1)$ vectors of ones. $\mathbf{u}_{\mathbf{z}}$ are $(N \times 1)$ vectors of iid individual firm error terms with $\mathbb{E}\left(\mathbf{u}_{\mathbf{z}}\right)=\mathbf{0}$ and $\mathbb{E}\left(\mathbf{u}_{\mathbf{z}} \mathbf{u}_{\mathbf{z}}^{\prime}\right)=\sigma_{u}^{2} \mathbf{I}_{\mathbf{N}}$, where $\mathbf{I}_{\mathbf{N}}$ is an identity matrix of size $\mathrm{N}$.

We introduce our aggregation scheme by defining the following matrix:

$$
\mathbf{M}=\left\{\begin{array}{cccc}
M_{1}^{1} & M_{2}^{1} & \cdots & M_{Z}^{1} \\
M_{1}^{2} & M_{2}^{2} & \cdots & M_{Z}^{2} \\
\vdots & \vdots & \ddots & \vdots \\
M_{1}^{J} & M_{2}^{J} & \cdots & M_{Z}^{J}
\end{array}\right\}
$$

Hence, the aggregation in Equation (C.2) can be written in matrix notation as $\left(\mathbf{M} \otimes \mathbf{I}_{\mathbf{N}}\right) \mathbf{Y}$. With $\mathbf{A}=\left(\mathbf{M} \otimes \mathbf{I}_{\mathbf{N}}\right)$, we can write Equation (C.4) as

$$
\mathbf{A Y}=\mathbf{A G}+\mathbf{A F} \beta+\mathbf{A U}
$$

Therefore, it follows directly that we have $\mathbb{E}\left(\mathbf{A} \mathbf{U U}^{\prime} \mathbf{A}^{\prime}\right)$. Hence, the aggregation of firms into firm clusters produces heteroskedastic error terms since the values along the diagonal of $\mathbb{E}\left(\mathbf{A U}^{\prime} \mathbf{U}^{\prime} \mathbf{A}^{\prime}\right)$ differ.

To estimate the coefficient $\beta$, we define a standard projection matrix $\mathbf{Q}$ to de-mean observations

$$
\begin{array}{r}
\mathbf{Q}=\mathbf{I}_{\mathbf{N}}-\frac{1}{N} \mathbf{e}_{\mathbf{N}} \mathbf{e}_{\mathbf{N}}^{\prime} \\
\tilde{\mathbf{Q}}=\mathbf{I}_{\mathbf{Z}} \otimes \mathbf{Q}
\end{array}
$$

Thus, we have

$$
\begin{aligned}
\tilde{\mathbf{Q}} \mathbf{A Y} & =\tilde{\mathbf{Q}} \mathbf{A} \mathbf{G}+\tilde{\mathbf{Q}} \mathbf{A F} \beta+\tilde{\mathbf{Q}} \mathbf{A} \mathbf{U} \\
& =\tilde{\mathbf{Q}} \mathbf{A} \mathbf{F} \beta+\tilde{\mathbf{Q}} \mathbf{A} \mathbf{U}
\end{aligned}
$$

Therefore, it follows directly that the estimated coefficient has the following form:

$$
\hat{\beta}=\left(\mathbf{F}^{\prime} \mathbf{A}^{\prime} \tilde{\mathbf{Q}} \mathbf{A} \mathbf{F}\right)^{-1} \mathbf{F}^{\prime} \mathbf{A}^{\prime} \tilde{\mathbf{Q}} \mathbf{A} \mathbf{U}
$$

Since $\mathbb{E}(\mathbf{U})=\mathbf{0}$, we have $\mathbb{E}(\hat{\beta}-\beta)=0$, i.e., the estimator is unbiased. Under finite sample properties, the variance of $\hat{\beta}$ is

$$
\begin{aligned}
\mathbb{E}\left[(\hat{\beta}-\beta)(\hat{\beta}-\beta)^{\prime}\right] & = \\
& =\left(\mathbf{F}^{\prime} \mathbf{A}^{\prime} \tilde{\mathbf{Q}} \mathbf{A} \mathbf{F}\right)^{-1} \mathbf{F}^{\prime} \mathbf{A}^{\prime} \tilde{\mathbf{Q}} \mathbb{E}\left(\mathbf{A} \mathbf{U U}^{\prime} \mathbf{A}^{\prime}\right) \tilde{\mathbf{Q}} \mathbf{A} \mathbf{F}\left(\mathbf{F}^{\prime} \mathbf{A}^{\prime} \tilde{\mathbf{Q}} \mathbf{A F}\right)^{-1}
\end{aligned}
$$

Thus, it is straightforward to obtain heteroskedaticity-robust standard errors by applying a common sandwich estimator of variance to the aggregated data. 


\section{Appendix D. Additional Results}

Table D.1: Is Foreign Lending Affected Differently than Domestic Lending by Securities Trading? - No Data Imputation

Notes: In this table, we present the results for the regressions shown in Table 3 but do not impute data for the year 2016 for Economic Distance. Standard errors are clustered at the bank-firm cluster level. Significance levels: $\quad{ }^{*} p<0.1 ; \quad{ }^{* *} p<0.05 ; \quad{ }^{* * *} p<0.01$.

\begin{tabular}{|c|c|c|c|c|c|c|}
\hline & \multicolumn{6}{|c|}{ Dependent variable: $\Delta \log (\text { Loan Volume })_{j, i, t}$} \\
\hline & (1) & (2) & (3) & (4) & (5) & (6) \\
\hline${\text { Trading } \text { Member }_{i}}$ & $\begin{array}{c}-0.359^{* * *} \\
(0.041)\end{array}$ & $\begin{array}{c}-0.331^{* * *} \\
(0.040)\end{array}$ & $\begin{array}{c}-0.247^{* * *} \\
(0.031)\end{array}$ & & & \\
\hline Securities Trading ${ }_{i, t-1}$ & & & & $\begin{array}{c}-0.669^{* * *} \\
(0.149)\end{array}$ & $\begin{array}{c}-0.729^{* * *} \\
(0.148)\end{array}$ & $\begin{array}{c}-0.235^{* *} \\
(0.118)\end{array}$ \\
\hline Foreign Lending & $\begin{array}{c}-1.485^{* * *} \\
(0.033)\end{array}$ & & & $\begin{array}{c}-1.511^{* * *} \\
(0.034)\end{array}$ & & \\
\hline $\log ($ Distance $)$ & & $\begin{array}{c}-0.175^{* * *} \\
(0.004)\end{array}$ & & & $\begin{array}{c}-0.184^{* * *} \\
(0.004)\end{array}$ & \\
\hline Economic Distance & & & $\begin{array}{c}-0.065^{* * *} \\
(0.002)\end{array}$ & & & $\begin{array}{c}-0.061^{* * *} \\
(0.002)\end{array}$ \\
\hline $\log (\text { Total Assets })_{i, t-1}$ & $\begin{array}{c}0.647^{* * *} \\
(0.011)\end{array}$ & $\begin{array}{c}0.658^{* * *} \\
(0.011)\end{array}$ & $\begin{array}{c}0.572^{* * *} \\
(0.012)\end{array}$ & $\begin{array}{c}0.633^{* * *} \\
(0.012)\end{array}$ & $\begin{array}{c}0.648^{* * *} \\
(0.012)\end{array}$ & $\begin{array}{c}0.550^{* * *} \\
(0.012)\end{array}$ \\
\hline 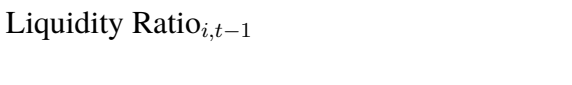 & $\begin{array}{l}3.176^{* * *} \\
(0.312)\end{array}$ & $\begin{array}{c}3.327^{* * *} \\
(0.311)\end{array}$ & $\begin{array}{l}2.015^{* * *} \\
(0.333)\end{array}$ & $\begin{array}{l}3.369^{* * *} \\
(0.316)\end{array}$ & $\begin{array}{l}3.584^{* * *} \\
(0.315)\end{array}$ & $\begin{array}{l}2.358^{* * *} \\
(0.337)\end{array}$ \\
\hline $\mathrm{ROA}_{i, t-1}$ & $\begin{array}{l}-0.386 \\
(1.959)\end{array}$ & $\begin{array}{l}-0.778 \\
(1.951)\end{array}$ & $\begin{array}{l}6.397^{* * *} \\
(2.130)\end{array}$ & $\begin{array}{l}3.079 \\
(1.946)\end{array}$ & $\begin{array}{c}2.529 \\
(1.936)\end{array}$ & $\begin{array}{l}8.799^{* * *} \\
(2.118)\end{array}$ \\
\hline Capital Ratio $i_{i, t-1}$ & $\begin{array}{c}4.950^{* * *} \\
(0.564)\end{array}$ & $\begin{array}{c}4.992^{* * *} \\
(0.564)\end{array}$ & $\begin{array}{l}3.851^{* * * *} \\
(0.595)\end{array}$ & $\begin{array}{c}5.610^{* * *} \\
(0.574)\end{array}$ & $\begin{array}{l}5.607^{* * *} \\
(0.572)\end{array}$ & $\begin{array}{l}4.134^{* * *} \\
(0.612)\end{array}$ \\
\hline Loans-To-Deposits $_{i, t-1}$ & $\begin{array}{c}0.101^{* * *} \\
(0.029)\end{array}$ & $\begin{array}{l}0.092^{* * *} \\
(0.029)\end{array}$ & $\begin{array}{c}0.128^{* * *} \\
(0.030)\end{array}$ & $\begin{array}{c}0.129^{* * *} \\
(0.030)\end{array}$ & $\begin{array}{c}0.120^{* * *} \\
(0.030)\end{array}$ & $\begin{array}{l}0.148^{* * *} \\
(0.030)\end{array}$ \\
\hline Trading Member $_{i}{ }^{*}$ Foreign Lending & $\begin{array}{c}0.406^{* * *} \\
(0.042)\end{array}$ & & & & & \\
\hline Trading Member $_{i} * \log ($ Distance $)$ & & $\begin{array}{c}0.045^{* * *} \\
(0.005)\end{array}$ & & & & \\
\hline Trading Member $_{i}{ }^{*}$ Economic Distance & & & $\begin{array}{c}0.010^{* * *} \\
(0.003)\end{array}$ & & & \\
\hline Securities Trading ${ }_{i, t-1} *$ Foreign Lending & & & & $\begin{array}{l}1.456^{* * *} \\
(0.152)\end{array}$ & & \\
\hline Securities Trading ${ }_{i, t-1} * \log ($ Distance $)$ & & & & & $\begin{array}{l}0.194^{* * *} \\
(0.018)\end{array}$ & \\
\hline Securities Trading ${ }_{i, t-1} * E^{*}$ conomic Distance & & & & & & $\begin{array}{c}0.013 \\
(0.009) \\
\end{array}$ \\
\hline $\begin{array}{l}\text { Observations } \\
\text { Adjusted } \mathrm{R}^{2}\end{array}$ & $\begin{array}{c}267,326 \\
0.413\end{array}$ & $\begin{array}{c}267,326 \\
0.416\end{array}$ & $\begin{array}{c}252,882 \\
0.382\end{array}$ & $\begin{array}{c}267,326 \\
0.413\end{array}$ & $\begin{array}{c}267,326 \\
0.416\end{array}$ & $\begin{array}{c}252,882 \\
0.381\end{array}$ \\
\hline Firm Cluster-Year FE & YES & YES & YES & YES & YES & YES \\
\hline Bank Country-Year FE & YES & YES & YES & YES & YES & YES \\
\hline
\end{tabular}


Table D.2: Is Foreign Lending Affected Differently than Domestic Lending by Securities Trading? - Inter-EEA lending as domestic lending

Notes: In this table, we present the results for the regressions shown in Table 3 but all lending where bank and borrower are incorporated in the European Economic Area (EEA) is considered domestic lending in the definition of the variables Foreign Lending, log(Distance), and Economic Distance (i.e., all three variables are zero for inter-EEA loans). Standard errors are clustered at the bank-firm cluster level. Significance levels: ${ }^{*} p<0.1 ;{ }^{* *} p<0.05 ;{ }^{* * *} p<0.01$.

\begin{tabular}{|c|c|c|c|c|c|c|}
\hline & \multicolumn{6}{|c|}{ Dependent variable: $\Delta \log (\text { Loan Volume })_{j, i, t}$} \\
\hline & $(1)$ & $(2)$ & (3) & (4) & $(5)$ & (6) \\
\hline Trading Member $_{i}$ & $\begin{array}{l}-0.389^{* * *} \\
(0.034)\end{array}$ & $\begin{array}{l}-0.408^{* * *} \\
(0.034)\end{array}$ & $\begin{array}{c}-0.232^{* * *} \\
(0.030)\end{array}$ & & & \\
\hline Securities Trading $_{i, t-1}$ & & & & $\begin{array}{c}-0.811^{* * *} \\
(0.120)\end{array}$ & $\begin{array}{l}-0.886^{* * *} \\
(0.120)\end{array}$ & $\begin{array}{c}-0.232^{* *} \\
(0.111)\end{array}$ \\
\hline Foreign Lending & $\begin{array}{c}-1.260^{* * *} \\
(0.031)\end{array}$ & & & $\begin{array}{c}-1.348^{* * *} \\
(0.031)\end{array}$ & & \\
\hline $\log ($ Distance $)$ & & $\begin{array}{c}-0.148^{* * *} \\
(0.004)\end{array}$ & & & $\begin{array}{c}-0.158^{* * *} \\
(0.004)\end{array}$ & \\
\hline Economic Distance & & & $\begin{array}{c}-0.060^{* * *} \\
(0.002)\end{array}$ & & & $\begin{array}{c}-0.059^{* * *} \\
(0.002)\end{array}$ \\
\hline $\log (\text { Total Assets })_{i, t-1}$ & $\begin{array}{c}0.641^{* * *} \\
(0.012)\end{array}$ & $\begin{array}{c}0.645^{* * *} \\
(0.012)\end{array}$ & $\begin{array}{c}0.552^{* * *} \\
(0.012)\end{array}$ & $\begin{array}{c}0.623^{* * *} \\
(0.011)\end{array}$ & $\begin{array}{c}0.627^{* * *} \\
(0.011)\end{array}$ & $\begin{array}{c}0.530^{* * *} \\
(0.012)\end{array}$ \\
\hline 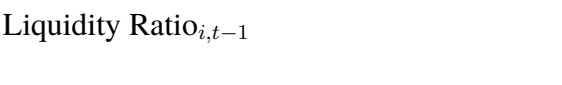 & $\begin{array}{c}2.960^{* * *} \\
(0.314)\end{array}$ & $\begin{array}{c}3.039^{* * *} \\
(0.313)\end{array}$ & $\begin{array}{c}1.949^{* * *} \\
(0.318)\end{array}$ & $\begin{array}{c}3.263^{* * *} \\
(0.316)\end{array}$ & $\begin{array}{c}3.363^{* * *} \\
(0.316)\end{array}$ & $\begin{array}{c}2.302^{* * *} \\
(0.323)\end{array}$ \\
\hline $\mathrm{ROA}_{i, t-1}$ & $\begin{array}{l}-1.427 \\
(1.978)\end{array}$ & $\begin{array}{l}-1.398 \\
(1.975)\end{array}$ & $\begin{array}{c}3.069 \\
(2.067)\end{array}$ & $\begin{array}{c}2.103 \\
(1.966)\end{array}$ & $\begin{array}{c}2.037 \\
(1.963)\end{array}$ & $\begin{array}{l}5.500^{* * *} \\
(2.054)\end{array}$ \\
\hline Capital Ratio $_{i, t-1}$ & $\begin{array}{c}4.505^{\text {*** }} \\
(0.568)\end{array}$ & $\begin{array}{c}4.483^{* * *} \\
(0.568)\end{array}$ & $\begin{array}{c}4.072^{* * *} \\
(0.585)\end{array}$ & $\begin{array}{c}5.110^{* * *} \\
(0.581)\end{array}$ & $\begin{array}{c}5.084^{* * *} \\
(0.580)\end{array}$ & $\begin{array}{c}4.272^{* * *} \\
(0.601)\end{array}$ \\
\hline Loans-To-Deposits $_{i, t-1}$ & $\begin{array}{c}0.088^{* * *} \\
(0.029)\end{array}$ & $\begin{array}{c}0.084^{* * *} \\
(0.029)\end{array}$ & $\begin{array}{c}0.115^{* * *} \\
(0.029)\end{array}$ & $\begin{array}{c}0.123^{* * *} \\
(0.030)\end{array}$ & $\begin{array}{c}0.119^{* * *} \\
(0.030)\end{array}$ & $\begin{array}{c}0.135^{* * *} \\
(0.029)\end{array}$ \\
\hline Trading Member $_{i}{ }^{*}$ Foreign Lending & $\begin{array}{c}0.470^{* * *} \\
(0.038)\end{array}$ & & & & & \\
\hline Trading Member $_{i} * \log ($ Distance $)$ & & $\begin{array}{c}0.059^{* * *} \\
(0.004)\end{array}$ & & & & \\
\hline Trading Member $_{i} *$ Economic Distance & & & $\begin{array}{c}0.009^{* * *} \\
(0.002)\end{array}$ & & & \\
\hline Securities Trading $_{i, t-1} *$ Foreign Lending & & & & $\begin{array}{c}2.101^{\text {*** }} \\
(0.132)\end{array}$ & & \\
\hline Securities Trading $g_{i, t-1} * \log ($ Distance $)$ & & & & & $\begin{array}{c}0.259^{* * *} \\
(0.015)\end{array}$ & \\
\hline Securities Trading $_{i, t-1} *$ Economic Distance & & & & & & $\begin{array}{l}0.021^{* *} \\
(0.008)\end{array}$ \\
\hline Observations & 267,326 & 267,326 & 266,257 & 267,326 & 267,326 & 266,257 \\
\hline Adjusted $\mathrm{R}^{2}$ & 0.406 & 0.408 & 0.386 & 0.407 & 0.408 & 0.386 \\
\hline Firm Cluster-Year FE & YES & YES & YES & YES & YES & YES \\
\hline Bank Country-Year FE & YES & YES & YES & YES & YES & YES \\
\hline
\end{tabular}

